\title{
Does Membership in International Organizations Increase Governments' Credibility? Testing the Effects of Delegating Powers
}

\author{
AXEL DREHER \\ STEFAN VOIGT
}

CESIFO WORKING PAPER No. 2285

CATEgory 2: Public ChOice

APRIL 2008

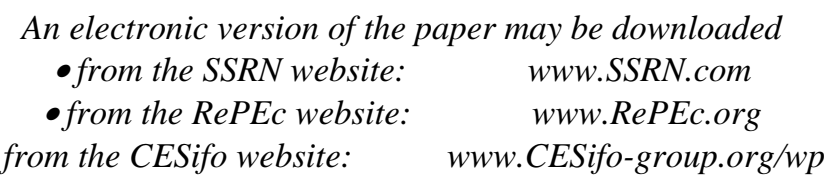




\title{
Does Membership in International Organizations Increase Governments' Credibility? Testing the Effects of Delegating Powers
}

\begin{abstract}
This paper analyzes whether nation-state governments can increase their credibility by becoming members of international organizations. Credibility is an important asset because it determines the real interest rate and is expected to have an important impact on investment and growth. It is hypothesized that the degree of delegation to international organizations can improve the credibility of nation-state governments. This hypothesis is tested by introducing three new indicators for international delegation. On the basis of panel data for up to 136 countries and the time period from 1984 to 2004, membership in international organizations is significantly and robustly linked with better credibility, here proxied for by country risk ratings. Two more results stand out: the longer a country has had a high level of membership, the higher its credibility, ceteris paribus; and: the credibility-enhancing effect is strongest in countries whose domestic institutions are weak.
\end{abstract}

JEL Code: F02, F21, H11, K33, P26.

Keywords: delegation of competence, credibility, dilemma of the strong state, international organizations.

Axel Dreher
KOF Swiss Economic Institute
ETH Zurich
Weinbergstrasse 35
8092 Zurich
Switzerland
mail@axel-dreher.de

Axel Dreher

ETH Zurich

inbergstrasse 35

8092 Zurich

mail@axel-dreher.de

\author{
Stefan Voigt \\ Marburg Center for \\ Institutional Economics \\ Barfüßertor 2 \\ 35032 Marburg \\ Germany \\ voigt@wiwi.uni-marburg.de
}

\section{April 2008}

We thank Anne van Aaken, Lorenz Blume, Georgios Chortareas, Michael Ebeling, Martin Gassebner, Tobias Göthel, Roland Kirstein, Eric Neumayer, Viet Quoc Nguyen, Eric Posner, Janina Satzer, Mary Shirley, Hans-Bernd Schäfer, George Tridimas, Jan Wagner, seminar participants at the conference on International Conflict Resolution (Saarbrücken 2004), the International Society for New Institutional Economics (Barcelona 2005), and the European Public Choice Society Meeting (Jena 2008) for helpful comments and Lorenz Blume for excellent research assistance. Support of the VolkswagenFoundation for the project "Institutions beyond the Nation-State" is gratefully acknowledged. 


\section{Introduction}

Membership in international organizations is often considered to have beneficial consequences for their member countries - as well as for the international community at large. The WTO is supposed to enhance international trade, the IMF is supposed to stabilize the international financial system, the UN are supposed to increase security and peace to name but a few possible examples. But what do we really know about the consequences of being a member in international organizations? In a recently published paper, Rose (2004) was unable to show that GATT/WTO membership had increased international trade. However, there is evidence that membership in international organizations bears direct benefits for these members: Temporary members of the UN Security Council, e.g., receive larger loans from the US, as well as more programs and projects from the IMF and the World Bank (Kuziemko and Werker 2006, Dreher, Sturm and Vreeland 2006, 2007). Countries serving on the Board of Executive Directors at the World Bank receive substantially larger credits than other countries (Kaja and Werker 2007). In this paper, we are interested in a slightly different question, namely whether membership in International Organizations (IOs) increases the credibility of member countries - and thus confers privileges onto their members.

It has often been pointed out that it can be a disadvantage to be too strong (e.g. Weingast 1993). A state that is strong enough to protect private property rights and to enforce private contracts is also strong enough to expropriate private wealth. This could be called the dilemma of the strong state. Rational subjects know this and will therefore invest less than they would if they could be sure that the state will not misuse its strength. States that have not had the chance to build up a reputation as meticulously sticking to their own promises will be especially affected. In such cases, the creation of domestic independent agencies will often not be a credible commitment because such agencies can be abolished with relative ease. It might therefore be rational for these countries to delegate relatively more powers internationally. Majone $(1996,12)$ has even argued that "credibility, rather than the legitimate use of coercion is now the most valuable resource of policy-makers." We test whether policy-makers can "buy" credibility by delegating powers internationally - or whether they will have to "make" it on the nation-state level.

Levy and Spiller $(1994,210)$ have dealt with the issue of regulatory commitment and have hypothesized that countries that do not have an independent judiciary will have difficulties to develop regulatory systems which attract substantial levels of private investment. In such cases, "alternative mechanisms of securing commitment (like international guarantees) will be necessary (ibid.)." Increasing one's credibility via international delegation appears a plausible idea. Yet, we know very little about the 
economic effects of such delegation. ${ }^{1}$ This paper aims at providing some preliminary answers to the question whether international delegation of competences increases government credibility.

We construct three different indicators to measure the degree of international delegation that a government has committed to. On the basis of up to 136 countries, all three indicators are significant for explaining the observed variation in the countries' risk ratings that are used as a proxy for credibility here. This is the case even after controlling for other variables such as openness, government consumption, GDP growth or the debt-to-export ratio. For countries whose domestic institutions are weak, membership in international organizations has particularly important effects. Membership in the GATT/WTO, membership in the International Center for the Settlement of Investment Disputes (ICSID), and ratification of the Optional Protocol are particularly conducive to boost credibility.

In this paper, the delegation decisions of governments are taken as exogenously given. ${ }^{2}$ We are thus not interested in explaining delegation decisions but in the consequences of delegation decisions. The remainder of the paper is organized as follows: the next section contains a number of arguments in favor of the presupposition that the international delegation of powers could have credibility-enhancing effects. Section three proposes a number of ways to make international delegation measurable - and thus comparable. In section four, our estimation approach is presented and section five presents the central results. Section six contains a number of robustness tests and section seven concludes.

\section{Why Should International Delegation Enhance Credibility?}

\subsection{Some Theory}

Credibility can be an important asset of a government. If a government that promises to enforce private property rights is credible, then actors will invest more than if the government was not credible. Higher investment levels translate into additional income. This, in turn, leads to higher utility levels for both the governed and the governing because higher (aggregate) income also means increased tax revenue. The credibility of

1 As notable exceptions, Marchesi and Thomas (1999) and Marchesi and Sabani (2007) analyze "delegated monitoring" to the International Monetary Fund.

2 The decision whether to delegate domestically or internationally has been analyzed by Voigt and Salzberger (2002); Tallberg (2002) deals with the decision to delegate to a supranational organization, namely the EU. 
a government can thus make everybody better off. Additionally, income growth will often make governments more popular.

The separation of powers has often been discussed as a way to increase government credibility (Landes and Posner 1975, Barzel 1997, Tsebelis 2002). Beyond the conventional separation into the three functions of legislating, executing and adjudicating, the delegation to independent or non-majoritarian institutions has received a lot of attention lately (see, e.g., Majone 2001 or Voigt and Salzberger 2002). Independent central banks are the most frequently cited example: in the long run, everybody profits from stable money. In the short run, politicians can, however, increase their popularity by increasing monetary supply. If citizens expect this, the short-term positive effects will not materialize but the policy will nevertheless be costly because it will lead to a higher inflation rate. Delegating monetary authority to an independent central bank can be interpreted as a solution to the problem of timeinconsistent preferences as introduced by Kydland and Prescott (1977). This problem is not unique to monetary policy but can be identified with regard to a variety of government policies including, e.g., environmental and competition policy. Correspondingly, many states have introduced independent agencies that are responsible for policies in these areas.

It would thus seem that rational nation state governments should aim at increasing their credibility by delegating some competence to independent agencies. Yet, creating such agencies and respecting their independence are not identical. Decision-makers who are subject to time-inconsistent preferences and who have delegated decision-making power might be tempted to interfere with the decisions of their agents once a certain decision has to be made. Worse yet, unsatisfied delegators might simply get rid off their delegatees or even abolish the independent agency altogether. This problem has been coined "second order commitment problem" (Moser 1999). On a worldwide scale, the effective average term-length of both supreme court judges and central bank governors is substantially below the term-length to be expected according to the statutes of those agencies. $^{3}$ Formal delegation is thus not sufficient to solve the problem of time inconsistency. Hence the question is whether other institutional arrangements - like the delegation of competence to IOs - are more likely to make government promises credible.

3 The effective average term-length of the members of the Supreme Court of Paraguay between 1960 and 1990 has, e.g., been a mere 1.1 years (Henisz 2000). Many states have judiciaries that are formally quite independent. But de facto judicial independence is only loosely correlated with de jure independence (the correlation coefficient between the two being 0.22; see Feld and Voigt 2003). 
Actors with time-inconsistent preferences will make decisions that are not in their own long-term interest. They thus have an interest in restructuring the relevant decisionmaking situations. Rational actors with time-inconsistent preferences will try to transform simple promises (e.g., to enforce private property rights) into credible commitments by modifying the relevant payoffs. If, once the time has come to honor or break one's promises, honoring one's promises leads to higher utility than breaking them and this is common knowledge among the participating actors, a simple promise has been transformed into a credible commitment.

One can think of the relevant interactions as a simple non-iterated game: in the first stage, government announces its policies (it could, e.g., announce to create private property rights and promise to enforce them), in the second stage, private actors make their investment decisions based on the credibility of government promises and in the third stage, government decides whether to honor its promises (enforce private property rights) or whether to break them (attenuate private property rights). After government has made its choice, the private actors can decide whether to take the case to court (stage four). If the court decides that government action was in congruence with its promises, the game is over. If the court, however, decides that government had broken its promises and that it was its duty to make up for it, the next stage follows in which government either accepts the court decision (i.e. makes up for the damage it has caused) or ignores the court decision.

Figure 1: A Stylized Game

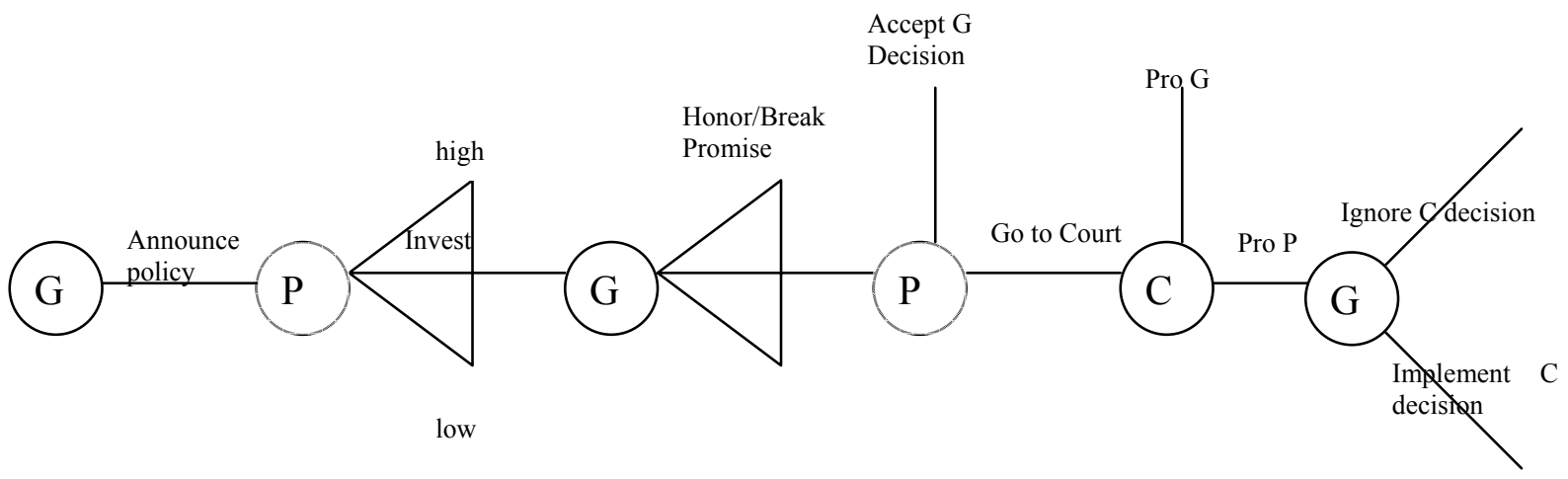

$\mathrm{G}=$ Government $\mathrm{P}=$ Private actors $; \mathrm{C}=$ Court 
The government will ignore the court decision if that is connected with a higher utility level than implementing it. Continuing to solve the game backwardly leads to the prediction that private actors will choose a low level of voluntary investment if government is expected to ignore the court decision. ${ }^{4}$

Repetition of the game greatly increases the number of possible equilibria. Governments might - but need not - honor their own promises because they know that what they do in this round of the game affects private actors' decisions in the next round of the game. Whether repetition makes governments comply depends inter alia on their time preferences.

The question thus is whether delegation of competence to IOs changes the payoffs in such a way that the government cannot make itself better off by breaking its own promises. We are thus interested in a comparative institutional analysis which compares domestic with international commitment capacities. In order to compare the two institutional alternatives, a look at a stylized game that could be played on the international level is necessary. Comparison of the payoffs will contain some information on likely equilibria.

The game tree of a game involving international delegation is quite similar to the one just discussed. In the international game the first stage does not simply consist of announcing a policy but announcing a policy by joining an international organization. If the respective IO has a court, stages four and five are exactly identical with those of the domestic game, if it does not, the decision whether a memberstate has played by the rules of the organization (has honored its promises) can be taken by some other actor (such as a general assembly). Just as in the domestic game, here too, governments have the option not to implement the decision made by the IO. If that was the last stage of the game, the likelihood of government implementing the (court) decision would prima facie not seem substantially higher than in the game played domestically. Yet, it can be argued that the international game consists of one more stage in which the other member states of the IO decide whether and how to sanction a government that ignores the decision made in stage five of the game. Possible sanctions include the freezing of financial aid, the refusal to make further concessions on trade issues, an economic embargo and - as ultima ratio - even the threat to go to war. Given a sufficiently high probability of being subject to sanctions, implementing the (court) decision might well prove to have a higher payoff than ignoring it.

\footnotetext{
4 If all actors are rational and this is common knowledge, it is hard to explain why government would promise to enforce private property rights in the first place.
} 
It could be argued that the domestic game also entails a seventh stage, in which the voters or the public could sanction government by, e.g., refusing to re-elect it, criticizing it in the press etc. One would then have to compare the expected value of the domestic sanction with that of the international sanction. If the expected value of the international sanction (but not that of the domestic one) leads the government to choose the implement-the-court-decision strategy, the international delegation of competence can be expected to have a credibility-enhancing effect. Assuming that governments might still be sanctioned domestically after having joined an $\mathrm{IO}$, the relevant expected value is the sum of the cost of the international plus the domestic sanction. ${ }^{5}$

It might be worthwhile pointing out some of the possible implications of the two games just described with regard to their capacity to enable governments to make credible commitments.

The first stage of both the domestic as well as the international game consists of announcing a policy. It seems reasonable to assume that policy announcements on the international level are much more stable than on the domestic level in the sense that changes in these announcements cannot be made unilaterally on the international level. Joining an existing IO can be interpreted as joining a given policy announcement. Given that the policy announcement is conducive to securing private property rights, joining an IO can entail higher credibility gains because the announced policies cannot be changed easily.

Let us now deal with the iterated version of the game: Suppose an IO has the reputation for implementing private property rights; membership is hence valuable and nonmembers are interested in joining - possibly even without appropriately modifying their own policies. A deterioration of the IOs' reputation would be the consequence. But the reputation can be up-held if incumbents are aware of that danger and specify the conditions under which newcomers may join in a way that secures their playing by the rules. The example of China having to modify a substantial number of domestic

5 On theoretical grounds, the relationship between the number and kinds of domestic constraints and delegation of competence to IOs is not entirely clear: on the one hand, it can be argued that international delegation will only confer higher credibility to governments if domestic constraints are not sufficiently credible; this would, hence, mean that they are substitutes. On the other hand, it can be argued that some domestic constraints are a necessary precondition for international delegation to have any beneficial effects, which would mean that they are complements.

Ex ante, it seems plausible to assume that a country that has consistently honored its own promises over a number of periods will be able to enjoy a high degree of credibility even though it is not a member of (m)any international organizations. This will, however, take a number of years and the hypothesis of this paper is that high degrees of credibility might be achieved faster if the country joins a number of IOs. This means that the periods directly following membership should display substantial increases in credibility; these additional credibility gains are expected to become smaller over time until the growth path converges to the "steady state" level of credibility. 
structures before being admitted to the WTO proves that this is more than a mere theoretical possibility. Carefully selecting club members is one way of keeping up the reputation of the club, but is, as such, not sufficient as countries who were admitted might decide not to play by the rules once they are members.

Before turning to formal sanctions and the issue of their reliable provision, let us shortly deal with the possibilities of "informal sanctions" that a government not implementing a (court) decision might be subject to. Investment decisions are decisions under uncertainty. Potential investors search for reliable information regarding the behavior of the government of the country in which they might invest. If the court - or the international body - making the decision on the compatibility of the government's actions with its announced policies is perceived to be impartial, its decisions might very well influence investment decisions although court decisions are not factually enforced. If one thinks of the game as an iterated one and assumes that potential investors rely on past government behavior to predict future behavior, a court decision against a government might deter potential investors from factually investing. This can be true in both the domestic and the international versions of the game.

Remember that we are interested in identifying mechanisms which make governments comply with their policy announcements when playing an international game but not (or to a lower degree) when playing the game domestically. It is interesting to compare the possible effects of public opinion of the game played domestically with the one played internationally. Suppose public opinion is critical of a government not honoring its promises no matter whether the game is played domestically or internationally. Further suppose that one's country's international reputation is an independent argument in the utility function of many citizens. It then follows that public opinion reacts more fiercely in the internationally embedded game. Whether the differential impact is sufficient to provoke a change in the dominant strategy of government is, of course, the decisive question.

We now turn to formal sanctions. Here, stages seven and four are crucial. Assuming that bringing suit is costly, one has to ask for the incentives to do so. If private actors expect the government to ignore court decisions, incentives to bring suit are very low. If state actors - in the international version of the game - cannot expect to be better off as a consequence of bringing suit, the corresponding incentives to bring suit would 
appear to be similarly low. One incentive for nation-state governments to bring suit could be their desire not to appear weak after others have reneged upon them. ${ }^{6}$

Sanctioning rule breakers is usually costly, the provision of sanctions thus amounts to the production of a public good and its provision can therefore not be taken for granted. The delegation of competence to IOs will be interpreted as a credible commitment to play by the rules of the organization only if rule-breaking behavior is sanctioned with high probability. The track-record of the IOs in sanctioning rule breakers is an important indicator in this regard: bailing out countries or prolonging credits although conditionality requirements have not been fulfilled reduces the value of membership in such an organization in terms of credibility gains for the respective country because rule-breaking behavior is not costly. ${ }^{7}$ It can thus not serve to increase a country's credibility. Given that the threat of IOs in sanctioning non-complying governments is sufficiently credible, governments will prefer to implement court decisions. This, in turn, will induce more actors to bring suit in the fourth stage of the game as they can expect that a favorable court decision will indeed make them better off.

Having to suffer substantial losses in utility after having broken a rule cannot only increase the likelihood of governments honoring their promises but also their desire to exit from an IO. High costs of sanctions can thus only be expected to increase credibility if exit is sufficiently costly. If the international delegation of powers can be reversed at low or even zero cost, delegation cannot be expected to increase credibility. Only if a government has to incur substantial costs if it tries to "renationalize" a policy competence can the delegation decision be expected to be interpreted as a credible commitment and hence to increase government credibility. ${ }^{8}$

\footnotetext{
6 As long as no actors have ever brought suit, government cannot have ignored a court decision. Backward induction can, hence, not be used to argue that incentives for bringing suit were low. This means that we can assume that at least one suit will be brought against the government if it reneges upon its promises. This can have the informal effects just discussed even if the government does not abide by the court decision.

7 See Marchesi and Sabani (2007) for a detailed discussion regarding compliance with program conditions of the International Monetary Fund. See also Vreeland (2006, 2007).

8 A discussant of the paper (Mary Shirley) pointed out that this approach towards credible commitment could also be modeled as a signaling game in which the costliness of the signal (membership in IOs) is crucial for its effect (here on the credibility). More broadly, it can be argued that the value of the signal of becoming a member of one (or more) IOs depends on (1) the reputation of the IO, (2) the cost of entry into the IO, (3) the costs of the sanctions in case of non-compliance with the rules of the IO, (4) the cost of exit from the IO. All four components should positively contribute to the value of the signal. In this paper, these four components are not dealt with in any detail. In a companion paper (Voigt 2006), the domestic costs of both joining and exiting from IOs have been ascertained by asking how many domestic players had to consent to either action with what majorities. It turns out that the more difficult it is to delegate competence internationally in the first place, the higher the ensuing credibility.
} 
To sum up: some theoretical possibilities for why the commitment capacity of governments could be enhanced by delegating some of their powers internationally have been described. In a nutshell, the idea is that by voluntarily tying their hands, governments can make themselves better off. Conventional wisdom has it, though, that IOs are hugely inefficient and ineffective organizations. ${ }^{9}$ The question thus is whether one can show empirically that some of the theoretically possible effects do play a role; that membership in IOs does indeed improve governments' capacity to credibly commit themselves - and that membership hence does indeed have its privileges. In order to do so, the possible transmission channels will be spelled out in the next sub-section, followed by some considerations how they can be put to an empirical test in section 3 .

\subsection{Possible Transmission Mechanisms}

If delegation of competence to IOs enhances the commitment capacity of nation-state governments, then countries that are members in the respective IOs should enjoy higher credibility than non-members, ceteris paribus. This should be reflected in a number of objective variables such as interest rates and (foreign direct) investment but also in more subjective variables such as country risk and creditworthiness rankings as well as security of property rights evaluations.

At the end of the day, we are not interested in subjective evaluations but in hard facts. It seems plausible to assume that high levels of government credibility should also be conducive to (foreign direct) investment as well as to low interest rates (Figure 2).

\footnotetext{
9 According to Vaubel, Dreher and Soylu (2007), inefficiency in international organizations can partly be attributed to principal-agent problems. They show that staff size of international organizations depends negatively on (an interaction with) the financing share of the largest contributor (his incentive to monitor). For an excellent overview of principal-agent problems in international organizations see Vaubel (2006).
} 
Figure 2: Potential transmission mechanisms

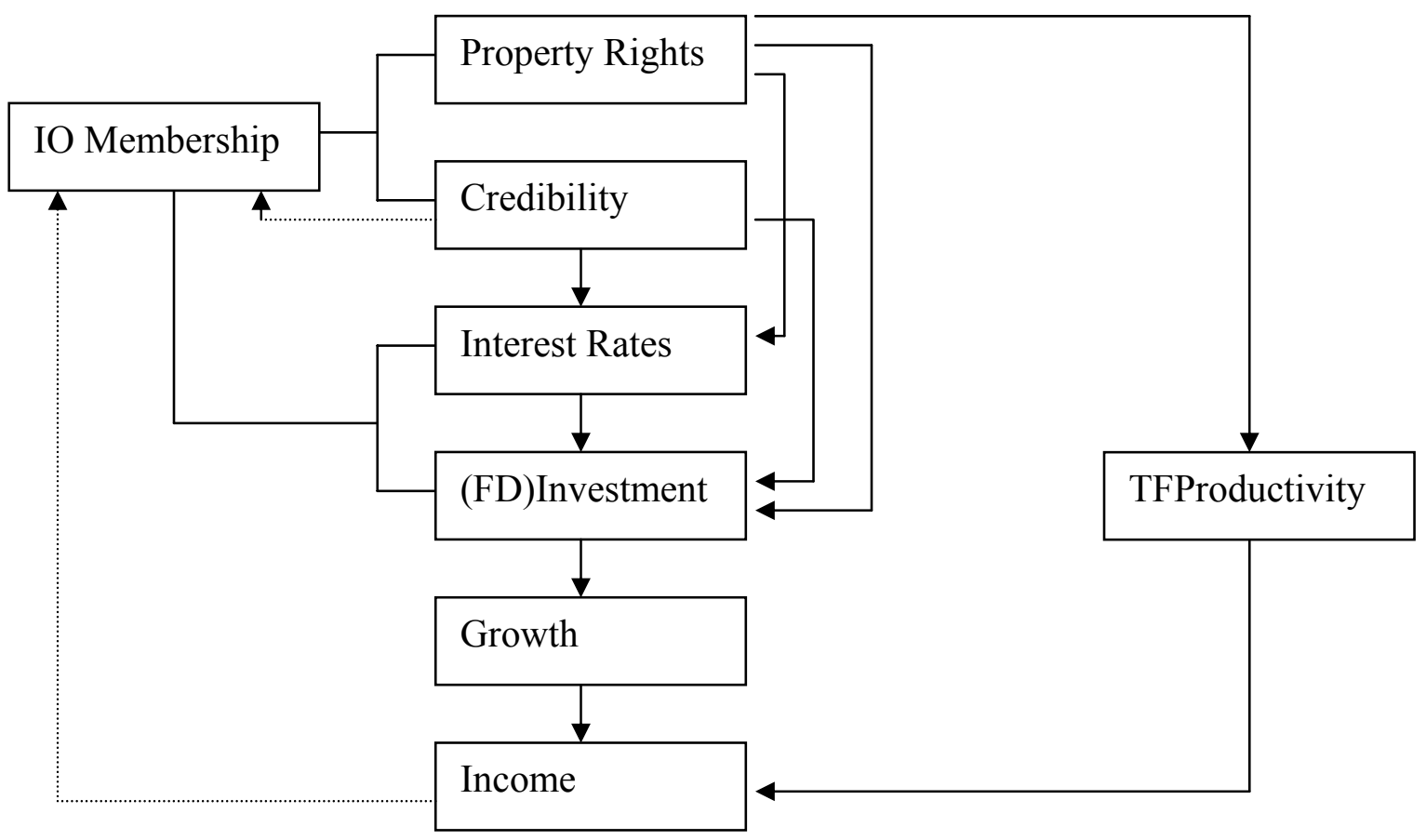

The security of property rights should be positively correlated with high levels of total factor productivity. All of these positive effects should lead to increased rates of economic growth and, over time, to higher levels of income.

The two dotted lines indicate two possible endogeneity problems. First, it could be the case that countries with high incomes have fewer difficulties of joining IOs than countries with low incomes. Secondly, it could be the case that countries that enjoy higher credibility levels have fewer difficulties of joining IOs than countries with bad country risk ratings. Possibilities to control for these potential endogeneity problems will be discussed below.

This section has presented the basic economic rationale for delegating powers internationally. Some possible cost components that can result from not following the rules of the international game have been mentioned, many of them, however, are very difficult to quantify. We therefore now turn to search for proxies that allow us to assess the effects of the international delegation of competence on credibility empirically.

\section{Making International Delegation Measurable}

In order to analyze whether and to what extent the international delegation of competences can increase a country's credibility, one needs to devise tests with which that proposition can be assessed empirically. This section serves to sketch some 
possible tests but also to highlight some of the conceptual problems in devising such tests. Prima facie, it would seem straightforward to assume that the higher a country's overall degree of integration into the international community, the more credible its promises should be. A general indicator measuring some "integration degree" could consist of counting the number of inter-governmental IOs that a country is member of in a particular year and to compare them with the membership numbers of other countries. This is indeed our first indicator of international delegation, taken from Dreher, Gaston and Martens (2008).

This is, of course, a very crude indicator with definite disadvantages. It has been noted that the number of IOs has been steadily rising since World War II (Union of International Associations 2006). The rising number of IOs as such is, however, not equivalent with an increase in the delegation of powers. Ideally, one would thus not count the number of memberships but the degree to which powers have been delegated onto the international level. Further, some countries appear to be "more integrated" simply because they are geographically located in world areas that have more regional IOs. This indicator thus contains serious bias. Furthermore, no distinction whatsoever is made between the substantive areas in which IOs are active, i.e., IOs like the international financial institutions or the WTO are counted just as heavily as IOs that have nothing to do with property rights or are even inimical to their protection. Different degrees of membership, which might indicate different degrees of "earnestness" in membership are not taken explicitly into account in this approach either: whether a state has ratified additional conventions within the realm of an IO could be valuable information that is not used with this very simple indicator.

We therefore developed a second indicator

- which is confined to IOs that are active on a global scale,

- which is confined to IOs that put some weight on the protection of property rights and possibly endow individuals with standing before international dispute settlement mechanisms and

- that takes "degrees of membership" explicitly into account. Ratified conventions within these IOs that promise to be either particularly relevant for the protection of private property rights or to indicate a high degree of earnestness, e.g., because membership implies monitoring by international groups, sanctions are severe etc. are explicitly recognized.

This leads to an "unweighted" indicator. We further developed a weighted version of this indicator that does not simply count whether a country is member of our subset of IOs or not but that counts the number of years it has already been a member. This "weighted indicator" thus takes into account explicitly the possibility that the length of 
membership could have an effect on the degree of credibility it conveys. ${ }^{10}$ Thus, the unweighted indicator simply adds up the number of "qualifying" organizations which a nation-state is member of. The weighted indicator, in turn, weighs membership with the number of years that a country has been a member. ${ }^{11}$

Membership in the following IOs and - more specifically - in the following conventions has been taken into account in the construction of the two indicators:

(1) Membership in the GATT/WTO, which reduces the discretionary leeway of governments with regard to trade policy.

(2/3) Membership in the International Bank for Reconstruction and Development (IBRD): Membership in the IBRD has become almost universal which means that little variation results and membership does not convey a valuable signal anymore. This has led us to look at membership of two sub-organizations, namely the International Finance Corporation (IFC) and the International Center for the Settlement of Investment Disputes (ICSID). A dummy for membership in the IFC is included because its aim is to promote private enterprise by improving the investment climate. If it is effective, membership could thus improve members' credibility.

Membership in ICSID gives private investors who believe that a member-state to ICSID has not complied with its contractual obligations the possibility of a trial against that state. Members thus explicitly choose to have their behavior monitored by third parties. Once the parties have consented to arbitration under ICSID, neither party can unilaterally withdraw. Arbitration under ICSID amounts to a far-reaching delegation of competence since all contracting states to ICSID are required by the Convention to enforce ICSID arbitral awards. This is called res iudicata effect by legal scholars. The role of ICSID has become ever more important over time: advance consent by governments to submit investment disputes to its arbitration can be found in some 20 investment laws and in more than 900 bilateral investment treaties as well as in four multilateral trade and investment treaties (inter alia NAFTA). It is, hence, not surprising that the number of cases submitted to ICSID has markedly increased in recent years. This remains the case even if the filings connected to Argentina's recent crisis are not taken into consideration (ICSID webpage).

10 Remember that the credit cards of the organization that claims that membership had its privileges also contain the information "member since x" suggesting that longer membership translates into higher credibility.

11 Reynaud and Vauday (2007) use a similar weighting methodology to build an index of NonProliferation Treaties to capture countries' geopolitical weight. 
(4-7) Membership in the UN is even more universal than membership in the IBRD. But ratification of the International Convention for Civil and Political Rights (ICCPR) as well as ratification of the International Convention for Economic, Social, and Cultural Rights (ICESCR) are not as widespread. Whereas the Universal Declaration of Human Rights does not have a legally binding character, these two conventions are endowed with a supervisory committee that monitors implementation. The ICCPR guarantees basic individual rights, some of which can be interpreted as a precondition for secure property rights (freedom from torture and slavery, right to personal freedom and security), others as important aspects of the realization of the rule of law (right to a fair trial, prohibition of ex post facto laws etc.). The guarantees contained in the ICESCR are a lot more controversial with regard to their effect on the protection of private property rights. ${ }^{12}$ It could even be argued that some of them are inimical to the protection of private property rights. We have decided to take both covenants into account also in order to be able to compare the two effects on credibility. ${ }^{13}$

Variation can be further increased by counting the states that have agreed to the so-called Optional Protocol in which they promise to abolish capital punishment. Ratification of this optional protocol is not directly related to property rights issues but can be interpreted as a signal of a government's earnestness to implement the rules it has agreed to. Further, it is taken into account whether a government has ratified the "Convention on the Recognition and Enforcement of Foreign Arbitral Awards" - often also called the New York Convention. This convention specifies the conditions under which states promise to recognize and enforce arbitration awards that are not issued by state courts but by non-state courts.

Contracting parties often prefer arbitration courts over state courts because their decisions take the specific problems of the conflicting parties better into account than state courts, and decision-making takes less time than in state courts. Since they are voluntarily chosen by the contracting parties, the choice of private arbitration courts reveals the contracting parties' preferences. If contracting parties did not believe that their property rights were sufficiently protected in these courts, they would not choose them. It can hence be inferred that governments that announce that they will enforce foreign arbitration awards give

12 The Covenant contains, e.g., the right to work, the right to social security, the right to an adequate standard of living as well as the right to "the highest attainable standard of physical and mental health."

13 Distinguishing between four kinds of basic rights, namely basic human rights, property rights, civil rights, and social and emancipatory rights, Blume and Voigt (2007) find in a study of 137 countries that none of them is inimical to economic growth. 
up some of their sovereignty in favor of a better protection of private property rights.

(8) The International Court of Justice (ICJ) is the dispute settlement branch of the UN. UN-Members do not, however, have to accept its jurisdiction qua membership but can opt in to do so voluntarily. We therefore count whether the country has opted into compulsory jurisdiction by the ICJ in a particular year. ${ }^{14}$

The resulting unweighted indicator ranges between zero and one, with higher values indicating higher levels of membership. According to the indicator, 18 countries score one in the year 2006, while 7 countries show the lowest number of participation in international organizations of 0.06 . The weighted index is calculated by dividing the number of years a country is member in the respective organization by the maximum number of years membership is possible. The individual organizations receive again equal weight in the overall index. The resulting weighted index takes values between zero and 0.94, where higher values again represent higher levels of membership. According to the weighted index, Fiji, Kazakhstan, Tajikistan, Papua New Guinea, and Mozambique have delegated least competence internationally in the year 2006, whereas Norway, Sweden, Denmark, Finland, and Italy come in first. The appendix reports descriptive statistics.

\section{Data and Estimation Approach}

The purpose of this paper is to make first steps in answering the question whether the international delegation of competence reduces the credibility problems of governments. In the previous section, two possible proxies for the degree of international delegation have been discussed. We now turn to the choice of our dependent variable, namely the degree of credibility that is conjectured to be influenced by the degree to which governments have delegated competence internationally.

To proxy for "credibility" we suggest creditworthiness scores as assigned by various risk firms. This subjective indicator has the advantage of implicitly controlling for a number of factors that might influence a country's capacity to repay a large debt but that would be very difficult to control for using objective controls (Keefer and Knack 2003). ${ }^{15}$ As our main indicator, we use the country risk ratings produced by Euromoney

14 This variable is only included in the unweighted version of the indicator. Countries accepting ICJ jurisdiction with reservations were coded .5. Additionally, it would, of course, be interesting to take into account to what degree various countries factually implement ICJ dicta. But over the course of its existence, the ICJ has only pronounced some 100 decisions, which does not seem to be a sufficiently large base for that type of information.

15 With regard to creditworthiness ratings, Keefer and Knack $(2003,173)$ cite a study by Feder and Ross (1982) who show that out of a sample of 78 Euromarket loans for 34 countries, the interest rate 
on an annual basis. The choice of the country risk ratings as a proxy for a country's credibility is based on the assumption that good scores on risk ratings imply that a government's announcement to pay back loans as agreed upon is evaluated as credible. It is, hence, assumed that a country enjoys only one level of credibility. This is certainly a simplifying assumption, as it could be the case that a government always services its own debt on time (which would result in a high level of credibility) whereas it constantly attenuates the property rights of foreign direct investors. Yet, in order to keep things simple, we have decided to assume one uniform level of credibility for each country at a particular point in time.

Euromoney's risk ratings are based on the view of experts, heads of syndication and loans, as well as data from the World Bank, forfaiting houses and credit rating agencies. They are available since $1982 .{ }^{16}$ To obtain the overall country risk score, Euromoney assigns a weighting to nine categories. These are political risk $(25 \%$ weighting), economic performance (25\%), debt indicators $(10 \%)$, debt in default or rescheduled $(10 \%)$, credit ratings $(10 \%)$, access to bank finance $(5 \%)$, access to shortterm finance $(5 \%)$, access to capital markets $(5 \%)$, and discount on forfaiting $(5 \%)$. The resulting index ranges between zero and 100, with higher values representing higher credibility. ${ }^{17}$

Our regressions are pooled time-series cross-section analyses (panel data) and cover the period 1982-2004. Fixed country and time effects are significant at the one percent level in all estimated model specifications. They are included in all regressions but not shown in the tables. Since some of the data are not available for all countries or years, the panel data are unbalanced and the number of observations depends on the choice of explanatory variables. We include two lags of the dependent variable, which turned out to be highly significant according to most specifications. ${ }^{18}$

spread was strongly and inversely correlated with the creditworthiness ratings, controlling for maturity and length of the grace period. They also cite a study published by the General Accounting Office of the U.S. in 1994 that found the creditworthiness indicator to be similarly strongly related to the discount on 38 sovereign debt instruments, owed by 21 countries, which were traded on secondary markets. Arguably, objective indicators such as the variance in interest rates among countries or the level of investment measured either as total private investment or as foreign direct investment could also be used as proxies for credibility. While focusing on subjective indicators here, we plan to pursue this in future research.

16 Since 1993, the ratings are provided on a semi-annual basis. We used the September version.

17 Arguably, some components in this rating seem to determine country risk rather than being part of it. Good economic performance should, e.g., lead to an improvement in the risk rating whereas large outstanding debt should lead to its deterioration. We test for the stability of our results using an index excluding these components below.

18 Further lags of the dependent variable are not significant at conventional levels. The choice of lag structure does not affect our key results. 
The basic equation takes the following form:

$$
y_{i t}=\alpha+\beta_{1} y_{i t-1}+\beta_{2} y_{i t-2}+\beta_{3} I O_{i t-1}+\beta_{4}^{\prime} X+\eta_{i}+\lambda_{t}+\varepsilon_{i t},
$$

where $y_{i t}$ represents country risk in country $i$ at year $t$, and $\mathrm{IO}_{\mathrm{it}-1}$ is the respective (lagged) measure of membership in international organizations. $X$ is the vector of control variables, $\eta_{i}$ and $\lambda_{t}$ represent country and, respectively, year fixed effects, while $\varepsilon_{i t}$ represents the disturbance.

In choosing our control variables, we follow Cosset and Roy (1991), showing that country risk decreases significantly with higher GDP per capita. Consequently, we include per capita GDP as control variable. The data used are in constant 2000 US\$ in logarithmic form, taken from the World Bank's (2007) World Development Indicators. Appendix A shows the exact definitions of all variables with their sources, while Appendix B reports descriptive statistics.

With regard to economic variables, we additionally control for a country's openness, measured as the sum of exports plus imports normalized by GDP. This is based on the conjecture that higher degrees of openness are likely to be correlated with better risk ratings and membership in international organizations. Regarding political variables, we control for institutional quality employing the index of law and order from the International Country Risk Guide (ICRG) of the PRS Group. The law and order index assesses the strength and impartiality of the legal system as well as the popular observance of the law. It ranges from zero to six, where a higher number indicates a better system of law and order. This index is available over the period 1984-2004. Arguably, the degree of institutional quality is likely to reduce country risk.

As pointed out in the theoretical section, we want to deal with the question whether the effects of membership in international organizations - if there are, indeed, any - are a substitute for adequate domestic institutions or whether they complement them. We therefore interact membership in international organizations with our measure of domestic institutional quality:

$$
\begin{aligned}
& y_{i t}=\alpha+\beta_{1} y_{i t-1}+\beta_{2} y_{i t-2}+\beta_{3} I O_{i t-1}+\beta_{4} \text { Quality }_{i t}+ \\
& \beta_{5} I_{i t-1} * \text { Quality }_{i t}+\beta_{6}^{\prime} X+\eta_{i}+\lambda_{t}+\varepsilon_{i t}
\end{aligned}
$$

where Quality ${ }_{\text {it }}$ represents our measure of institutional quality.

As one problem, we have to deal with the potential endogeneity of country risk. It cannot be excluded that income or even credibility determines a country's prospects for joining IOs as already mentioned above. We pursue two strategies to deal with these selection problems. First, we test for the exogeneity of membership in (selected) international organizations using the Durbin-Wu-Hausman test. We employ (log) 
population size and the number of embassies located in a country as instrumental variables. Small countries depend more than large countries on being internationally integrated on various grounds: they are more likely to depend on imported goods, they are less likely to create and maintain a military defence of their own etc. The number of embassies located in a country have been suggested in Dreher, Gaston and Martens (2008) as proxy for political integration and are thus likely to affect membership in international organizations also (but are unlikely to affect country risk).

According to the results of the Durbin-Wu-Hausman test, the null hypothesis that membership in international organizations is exogenous can not be rejected at conventional levels of significance independent of the choice of indicator for membership.

As our second approach to deal with the potential endogeneity of the explanatory variables, we employ the system GMM estimator as suggested by Arellano and Bond (1991), Arellano and Bover (1995) and Blundell and Bond (1998). The dynamic panel GMM estimator exploits an assumption about the initial conditions to obtain moment conditions that remain informative even for persistent data. Results are based on the two-step estimator implemented by Roodman (2005) in Stata, including Windmeijer's (2005) finite sample correction. We apply the Sargan-Hansen test on the validity of the instruments used (amounting to a test for the exogeneity of the covariates) and the Arellano-Bond test of second order autocorrelation, which must be absent from the data in order for the estimator to be consistent. We treat GDP per capita as predetermined and all other variables as endogenous. As before, we include time dummies in the regression. In order to minimize the number of instruments in the regressions we collapse the matrix of instruments as suggested in Roodman (2006). To anticipate the results, the Sargan-Hansen test and the Arellano-Bond test do not reject these specifications at conventional levels of significance.

The next section presents the results.

\section{Results}

Table 1 shows the results for the basic setup. Column 1 includes membership in international organizations. Column 2 focuses on the unweighted indicator of membership in selected organizations as described above, while column 3 includes the weighted version instead. Columns 4-6 replicate the analysis employing the GMM estimator. 
Table 1: Membership in International Organizations and Country Risk (1984-2004)

\begin{tabular}{lcccccc}
\hline & $(1)$ & $(2)$ & $(3)$ & $(4)$ & $(5)$ & $(6)$ \\
\hline Membership in IOs (t-1) & 0.046 & & & 0.089 & & \\
& $(1.70)^{*}$ & & & $(2.14)^{* *}$ & & 1.902 \\
Membership in selected IOs, & & 2.804 & & & $(0.91)$ & \\
$\quad$ unweighted (t-1) & & $(2.18)^{* *}$ & & & & 4.349 \\
Membership in selected IOs, & & & 9.766 & & & $(1.71)^{*}$ \\
$\quad$ weighted (t-1) & & & $(2.34)^{* *}$ & & & \\
(log) GDP per capita & 1.574 & 2.463 & 2.403 & 1.967 & 3.870 & 3.443 \\
& $(0.93)$ & $(2.01)^{* *}$ & $(1.98)^{* *}$ & $(2.24)^{* *}$ & $(4.87)^{* * *}$ & $(4.75)^{* * *}$ \\
Law and order, index & 0.476 & 0.415 & 0.440 & 0.969 & 0.796 & 0.893 \\
& $(3.97)^{* * *}$ & $(4.31)^{* * *}$ & $(4.55)^{* * *}$ & $(2.87)^{* * *}$ & $(3.19)^{* * *}$ & $(3.77)^{* * *}$ \\
Trade (\% of GDP) & -0.017 & -0.013 & -0.011 & -0.005 & 0.004 & 0.009 \\
& $(1.34)$ & $(1.32)$ & $(1.14)$ & $(0.40)$ & $(0.25)$ & $(0.58)$ \\
Dependent variable (t-1) & 0.586 & 0.564 & 0.561 & 0.644 & 0.558 & 0.568 \\
& $(17.92)^{* * *}$ & $(20.43)^{* * *}$ & $(20.37)^{* * *}$ & $(10.66)^{* * *}$ & $(11.05)^{* * *}$ & $(11.63)^{* * *}$ \\
Dependent variable (t-2) & 0.029 & 0.047 & 0.045 & 0.095 & 0.060 & 0.062 \\
& $(0.93)$ & $(1.77)^{*}$ & $(1.72)^{*}$ & $(2.16)^{* *}$ & $(1.69)^{*}$ & $(1.74)^{*}$ \\
Constant & 3.897 & -2.013 & -3.788 & -12.674 & -17.495 & -16.608 \\
& $(0.31)$ & $(0.22)$ & $(0.41)$ & $(2.86)^{* * *}$ & $(4.36)^{* * *}$ & $(4.89)^{* * *}$ \\
\hline Method & OLS & OLS & OLS & GMM & GMM & GMM \\
Observations & 1647 & 2061 & 2061 & 1647 & 2061 & 2061 \\
Number of countries & 104 & 118 & 118 & 104 & 118 & 118 \\
Number of instruments & & & & 99 & 102 & 102 \\
R-squared (within) & 0.56 & 0.56 & 0.56 & & & \\
Arellano-Bond-Test (p-level) & & & & 0.11 & 0.74 & 0.77 \\
Sargan-Hansen Test (p-level) & & & & 0.11 & 0.11 & 0.10 \\
\hline
\end{tabular}

Notes: The dependent variable is Euromoney's risk rating. The OLS regressions include fixed country and year dummies; GMM includes year dummies.

(robust, absolute) t-statistics in parentheses: * significant at $10 \%$ level; ** significant at 5\% level; *** significant at $1 \%$ level.

As can be seen, country risk decreases with higher per capita GDP according to five of the six regressions, at least at the five percent level of significance. ${ }^{19}$ The index of law and order is highly significant according to all specifications, with the expected positive coefficient, and the same is true regarding the first lag of the dependent variable. The second lag of the dependent variable also enters with a positive coefficient and is significant at the ten percent level at least according to five of the six specifications. Openness to trade, to the contrary, is completely insignificant in all regressions. The estimated coefficients show that an increase in per capita GDP by ten percent reduces country risk by between $0.16-0.39$ points, while an improvement in the law and order index by one point reduces country risk by between $0.42-0.97$ points.

Turning to our variables of interest - membership in international organizations - the OLS results show that the simple membership count is significant at the ten percent

19 We also included the square of GDP per capita to test for potential non-linearity. The squared term is not significant at conventional levels while our main results are not affected. 
level, while the weighted and unweighted indicators are significant at the five percent level, all with the expected positive coefficient. This suggests that membership in international organizations indeed reduces country risk, independent of how the variable is constructed. However, when replicating the analysis employing the GMM estimator, the unweighted indicator loses its significance (while the other two indicators stay significant at the ten percent level at least). The weighted and unweighted indicators are constructed in a very similar fashion except for the number of years that a country has been member to an international organization which is only taken into account in the weighted version. This seems to indicate that time might indeed have an important impact on the level of credibility attributed to a country.

According to the OLS estimates of column 1, membership in one additional international organization reduces country risk by about 0.05 . The GMM estimates reported in column 3 show a somewhat higher marginal effect of 0.09. An increase in the weighted (unweighted) index of membership in selected organizations by 0.1 reduces risk by $0.98(0.3)$ according to the OLS estimates and $0.44(0.19)$ when estimated with GMM. Arguably, these are small but non-negligable effects, amounting to an elasticity of $0.04,0.04$, and 0.08 percent (columns 1, 2, and 3, respectively).

Comparing the results of the GMM and OLS specifications shows that the coefficients of lagged dependent variables are of similar magnitude, suggesting that the bias described by Nickell (1981) is not important here and that the results of the withingroups specification are valid. Given the similarity of the OLS and GMM results and the results of the Durbin-Wu-Hausman test reported above, we conclude that endogeneity is no an issue here and the more efficient OLS results can be taken at face value.

Table 2 investigates the question whether membership in international organizations is complementary to adequate domestic institutions or whether membership can serve as a substitute. As can be seen, membership in international organizations and the weighted indicator for membership in selected organizations remain significant at the one and, respectively, five percent level, while the unweighted indicator is marginally insignificant. Turning to the interaction terms, the results show a negative coefficient for the simple membership indicator, at the one percent level of significance. At the ten percent level of significance, the same is true for weighted membership in international organizations, while the interaction between law and order and the unweighted indicator is not significant at conventional levels. Calculating the marginal effect of membership at the minimum value of the law and order index of 0.83 among our sample, shows that membership in one additional organization reduces country risk by 0.09 points, significant at the one percent level. At the maximum value of 12 , 
membership in one additional organization decreases country risk by 0.007 , but the effect is not significant at conventional levels. The marginal effect is further illustrated in Graph 1. As can be seen, the marginal effect is significant at the ten percent level for low values of the law and order index, but not for high ones. Replicating the analysis for membership in selected organizations shows that at the minimum value of the law and order index an increase in the unweighted membership index by 0.1 reduces risk by 0.22 , while at the maximum, it reduces risk by 0.26 . Note, however, that both effects are marginally insignificant, as also illustrated by Graph 2. At the sample mean, the effect of weighted membership in specific organizations is significant at the ten percent level, indicating that an increase in membership by 0.1 reduces risk by 0.25 . The corresponding values at the minimum and maximum of law and order for the weighted indicator are 1.2 and, respectively, 0.6. While the effect of membership is significant at the five percent level at the minimum, it is not significant at the maximum (see Graph $3)$.

It is now interesting to ask whether membership in different IOs has differential impacts on countries' risk ratings. Table 3 contains the answer to this question. In addition to GDP per capita, law and order, and trade, we add - one at the time - one of our variables for time-weighted membership in the eight individual organizations (and unweighted acceptance of ICJ legislation) to the regressions. As can be seen, membership in the GATT/WTO, membership in the International Center for the Settlement of Investment Disputes (ICSID), and ratification of the Optional Protocol significantly reduce country risk. When included jointly, however, only GATT/WTO membership and membership in the ICSID remain significant at the ten percent level at least. These results are in line with intuition as both institutions seem to enhance the protection of property rights. ${ }^{20}$

To summarize, we find that membership in international organizations reduces country risk. In countries with low institutional quality - as measured by low scores on the law and order index - this effect is particularly pronounced, and highly significant, while the impact is smaller and not significant in countries scoring high on the law and order index. Our results suggest that countries with low credibility provided by their own institutional quality can "buy" credibility by becoming members in international organizations. The next section tests for the robustness of our results.

20 Note that we can not include the unweighted membership dummies as in many cases countries became member before the start of our sample period and the analysis includes fixed country effects. 
Graph 1: Marginal effect of membership in IOs, Table 2, Column 1

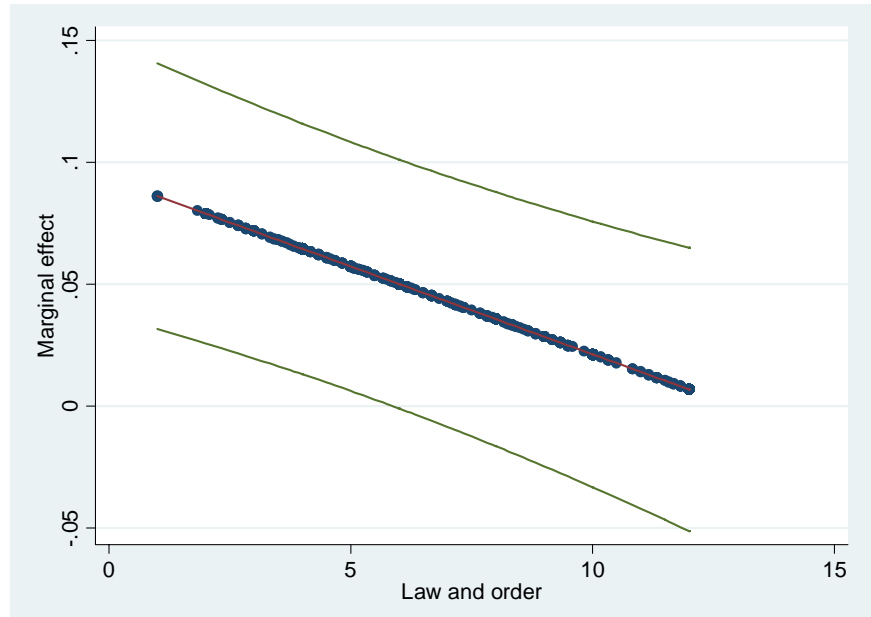

Graph 2: Marginal effect of membership in selected IOs, Table 2, Column 2

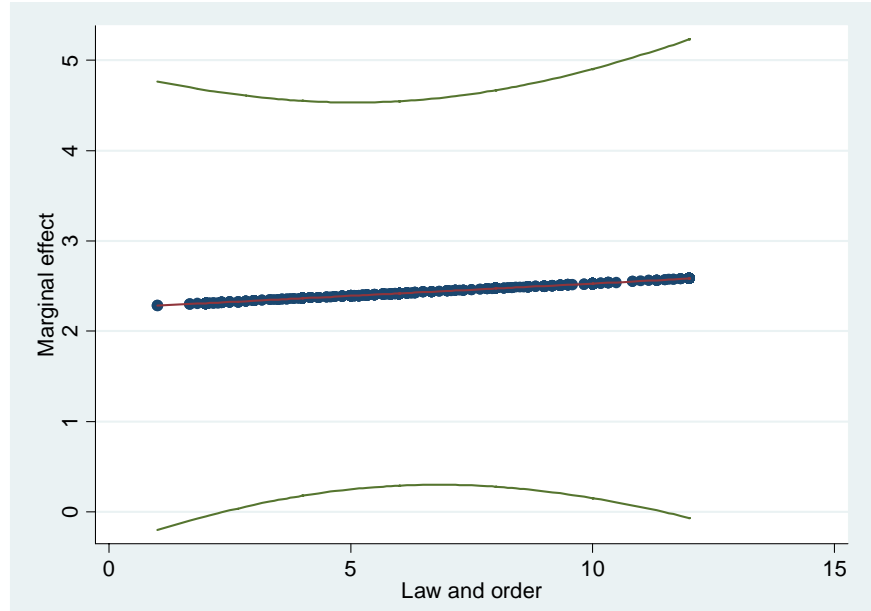

Graph 3: Marginal effect of membership in selected IOs, Table 2, Column 3

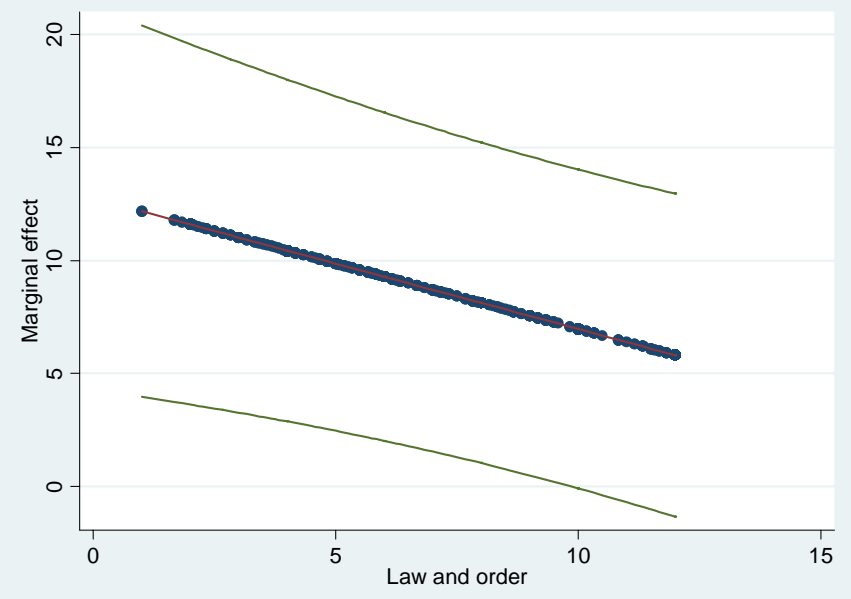


Table 2: International Organizations - Substitutes or Complements (OLS, 19842004)

\begin{tabular}{|c|c|c|c|}
\hline & (1) & $(2)$ & (3) \\
\hline Membership in IOs (t-1) & $\begin{array}{c}0.093 \\
(2.73)^{* * *}\end{array}$ & & \\
\hline $\begin{array}{l}\text { Membership in selected IOs, } \\
\text { unweighted (t-1) }\end{array}$ & & $\begin{array}{l}2.255 \\
(1.41)\end{array}$ & \\
\hline $\begin{array}{l}\text { Membership in selected IOs, } \\
\text { weighted (t-1) }\end{array}$ & & & $\begin{array}{l}12.752 \\
(2.47)^{* *}\end{array}$ \\
\hline Law and order & $\begin{array}{c}0.798 \\
(4.66)^{* * * *}\end{array}$ & $\begin{array}{c}0.402 \\
(3.09)^{* * *}\end{array}$ & $\begin{array}{c}0.607 \\
(4.27)^{* * *}\end{array}$ \\
\hline IOs * Law and order & $\begin{array}{c}-0.007 \\
(2.76)^{* * *}\end{array}$ & & \\
\hline $\begin{array}{l}\text { Selected IOs * Law and order } \\
\quad \text { (unweighted) }\end{array}$ & & $\begin{array}{l}0.027 \\
(0.17)\end{array}$ & \\
\hline $\begin{array}{l}\text { Selected IOs * Law and order } \\
\text { (weighted) }\end{array}$ & & & $\begin{array}{l}-0.579 \\
(1.94)^{*}\end{array}$ \\
\hline (log) GDP per capita & $\begin{array}{l}2.342 \\
(1.07)\end{array}$ & $\begin{array}{l}2.135 \\
(1.69)^{*}\end{array}$ & $\begin{array}{c}2.481 \\
(1.92)^{*}\end{array}$ \\
\hline Trade ( $\%$ of GDP) & $\begin{array}{l}-0.018 \\
(1.24)\end{array}$ & $\begin{array}{l}-0.014 \\
(1.38)\end{array}$ & $\begin{array}{l}-0.014 \\
(1.40)\end{array}$ \\
\hline Dependent variable $(\mathrm{t}-1)$ & $\begin{array}{c}0.543 \\
(15.91)^{* * *}\end{array}$ & $\begin{array}{c}0.545 \\
(20.63)^{* * *}\end{array}$ & $\begin{array}{c}0.544 \\
(20.72)^{* * *}\end{array}$ \\
\hline Dependent variable $(\mathrm{t}-2)$ & $\begin{array}{l}0.058 \\
(1.66)^{*}\end{array}$ & $\begin{array}{c}0.059 \\
(2.30)^{* *}\end{array}$ & $\begin{array}{c}0.057 \\
(2.23)^{* *}\end{array}$ \\
\hline Constant & $\begin{array}{l}-5.348 \\
(0.33)\end{array}$ & $\begin{array}{l}2.979 \\
(0.31)\end{array}$ & $\begin{array}{r}-3.145 \\
(0.30)\end{array}$ \\
\hline Observations & 1422 & 1997 & 1997 \\
\hline Number of countries & 104 & 118 & 118 \\
\hline R-squared (within) & 0.55 & 0.57 & 0.57 \\
\hline
\end{tabular}

Notes: The dependent variable is Euromoney's risk rating. All regressions include fixed country and year dummies.

(robust, absolute) t-statistics in parentheses: * significant at $10 \%$ level; ** significant at $5 \%$ level; *** significant at $1 \%$ level. 
Table 3: Membership in selected IOs and Country Risk (OLS, 1984-2004)

\begin{tabular}{|c|c|c|c|c|c|c|c|c|c|c|}
\hline & $(1)$ & $(2)$ & (3) & $(4)$ & $(5)$ & $(6)$ & $(7)$ & $(8)$ & $(9)$ & $(10)$ \\
\hline GATT/WTO (weighted) & $\begin{array}{l}15.556 \\
(3.85)^{* * *}\end{array}$ & & & & & & & & & $\begin{array}{l}17.680 \\
(3.38)^{* * *}\end{array}$ \\
\hline ICSID (weighted) & & $\begin{array}{l}5.878 \\
(2.28)^{* *}\end{array}$ & & & & & & & & $\begin{array}{l}5.585 \\
(1.74)^{*}\end{array}$ \\
\hline IFC (weighted) & & & $\begin{array}{l}5.617 \\
(1.53)\end{array}$ & & & & & & & $\begin{array}{l}2.545 \\
(0.47)\end{array}$ \\
\hline ICCPR (weighted) & & & & $\begin{array}{l}2.002 \\
(0.70)\end{array}$ & & & & & & $\begin{array}{l}-0.261 \\
(0.05)\end{array}$ \\
\hline ICESCR (weighted) & & & & & $\begin{array}{l}2.619 \\
(0.99)\end{array}$ & & & & & $\begin{array}{l}0.141 \\
(0.03)\end{array}$ \\
\hline Optional Protocol (weighted) & & & & & & $\begin{array}{l}4.024 \\
(1.93)^{*}\end{array}$ & & & & $\begin{array}{l}0.217 \\
(0.08)\end{array}$ \\
\hline New York Convention (weighted) & & & & & & & $\begin{array}{l}-1.374 \\
(0.41)\end{array}$ & & & $\begin{array}{l}0.863 \\
(0.22)\end{array}$ \\
\hline Folter Convention (weighted) & & & & & & & & $\begin{array}{l}0.365 \\
(0.39)\end{array}$ & & $\begin{array}{l}0.798 \\
(0.74)\end{array}$ \\
\hline ICJ (unweighted) & & & & & & & & & $\begin{array}{l}-0.482 \\
(0.34)\end{array}$ & $\begin{array}{l}-0.438 \\
(0.30)\end{array}$ \\
\hline Law and order & $\begin{array}{l}0.399 \\
(4.16)^{* * *}\end{array}$ & $\begin{array}{l}0.436 \\
(4.50)^{* * *}\end{array}$ & $\begin{array}{l}0.433 \\
(4.50)^{* * *}\end{array}$ & $\begin{array}{l}0.421 \\
(4.38)^{* * *}\end{array}$ & $\begin{array}{l}0.418 \\
(4.33)^{* * *}\end{array}$ & $\begin{array}{l}0.438 \\
(4.52)^{* * *}\end{array}$ & $\begin{array}{l}0.419 \\
(4.32)^{* * *}\end{array}$ & $\begin{array}{l}0.426 \\
(4.41)^{* * *}\end{array}$ & $\begin{array}{l}0.405 \\
(3.52)^{* * *}\end{array}$ & $\begin{array}{l}0.433 \\
(3.72)^{* * *}\end{array}$ \\
\hline (log) GDP per capita & $\begin{array}{l}2.812 \\
(2.33)^{* *}\end{array}$ & $\begin{array}{l}2.212 \\
(1.83)^{*}\end{array}$ & $\begin{array}{l}2.264 \\
(1.86)^{*}\end{array}$ & $\begin{array}{l}2.396 \\
(1.96)^{*}\end{array}$ & $\begin{array}{l}2.447 \\
(2.01)^{* *}\end{array}$ & $\begin{array}{l}2.411 \\
(2.00)^{* *}\end{array}$ & $\begin{array}{l}2.297 \\
(1.89)^{*}\end{array}$ & $\begin{array}{l}2.196 \\
(1.81)^{*}\end{array}$ & $\begin{array}{l}3.731 \\
(2.65) * * *\end{array}$ & $\begin{array}{l}4.354 \\
(3.11)^{* * *}\end{array}$ \\
\hline Trade ( $\%$ of GDP) & $\begin{array}{l}-0.016 \\
(1.57)\end{array}$ & $\begin{array}{l}-0.013 \\
(1.31)\end{array}$ & $\begin{array}{l}-0.013 \\
(1.31)\end{array}$ & $\begin{array}{l}-0.012 \\
(1.21)\end{array}$ & $\begin{array}{l}-0.012 \\
(1.20)\end{array}$ & $\begin{array}{l}-0.013 \\
(1.31)\end{array}$ & $\begin{array}{l}-0.012 \\
(1.21)\end{array}$ & $\begin{array}{l}-0.012 \\
(1.15)\end{array}$ & $\begin{array}{l}-0.026 \\
(2.15)^{* *}\end{array}$ & $\begin{array}{l}-0.031 \\
(2.59)^{* * *}\end{array}$ \\
\hline Dependent variable (t-1) & $\begin{array}{l}0.556 \\
(20.03)^{* * *}\end{array}$ & $\begin{array}{l}0.561 \\
(20.48)^{* * *}\end{array}$ & $\begin{array}{l}0.565 \\
(20.46)^{* * *}\end{array}$ & $\begin{array}{l}0.564 \\
(20.32)^{* * *}\end{array}$ & $\begin{array}{l}0.563 \\
(20.26)^{* * *}\end{array}$ & $\begin{array}{l}0.561 \\
(20.31)^{* * *}\end{array}$ & $\begin{array}{l}0.565 \\
(20.40) * * *\end{array}$ & $\begin{array}{l}0.565 \\
(20.46)^{* * *}\end{array}$ & $\begin{array}{l}0.552 \\
(17.67) * * *\end{array}$ & $\begin{array}{l}0.535 \\
(17.00)^{* * * *}\end{array}$ \\
\hline Dependent variable $(\mathrm{t}-2)$ & $\begin{array}{l}0.041 \\
(1.56)\end{array}$ & $\begin{array}{l}0.042 \\
(1.61)\end{array}$ & $\begin{array}{l}0.049 \\
(1.84)^{*}\end{array}$ & $\begin{array}{l}0.046 \\
(1.75)^{*}\end{array}$ & $\begin{array}{l}0.046 \\
(1.73)^{*}\end{array}$ & $\begin{array}{l}0.046 \\
(1.75)^{*}\end{array}$ & $\begin{array}{l}0.047 \\
(1.76)^{*}\end{array}$ & $\begin{array}{l}0.047 \\
(1.77)^{*}\end{array}$ & $\begin{array}{l}0.043 \\
(1.49)\end{array}$ & $\begin{array}{l}0.031 \\
(1.08)\end{array}$ \\
\hline Constant & $\begin{array}{l}-10.022 \\
(1.07)\end{array}$ & $\begin{array}{l}-1.004 \\
(0.11)\end{array}$ & $\begin{array}{l}-3.372 \\
(0.35)\end{array}$ & $\begin{array}{l}-0.815 \\
(0.09)\end{array}$ & $\begin{array}{l}-1.400 \\
(0.15)\end{array}$ & $\begin{array}{l}-0.777 \\
(0.09)\end{array}$ & $\begin{array}{l}1.055 \\
(0.12)\end{array}$ & $\begin{array}{l}1.204 \\
(0.13)\end{array}$ & $\begin{array}{l}-8.770 \\
(0.82)\end{array}$ & $\begin{array}{l}-28.248 \\
(2.31)^{* *}\end{array}$ \\
\hline Observations & 2061 & 2061 & 2061 & 2061 & 2061 & 2061 & 2061 & 2061 & 1630 & 1630 \\
\hline $\begin{array}{l}\text { Number of group(code) } \\
\text { R-squared }\end{array}$ & $\begin{array}{l}118 \\
0.57\end{array}$ & $\begin{array}{l}118 \\
0.56\end{array}$ & $\begin{array}{l}118 \\
0.56\end{array}$ & $\begin{array}{l}118 \\
0.56\end{array}$ & $\begin{array}{l}118 \\
0.56\end{array}$ & $\begin{array}{l}118 \\
0.56\end{array}$ & $\begin{array}{l}118 \\
0.56\end{array}$ & $\begin{array}{l}118 \\
0.56\end{array}$ & $\begin{array}{l}100 \\
0.55\end{array}$ & $\begin{array}{l}100 \\
0.56\end{array}$ \\
\hline
\end{tabular}

Notes: All regressions include fixed country and year dummies.

(robust, absolute) t-statistics in parentheses: * significant at $10 \%$ level; ** significant at $5 \%$ level; *** significant at $1 \%$ level. 


\section{Further Discussion and Tests for Robustness}

This section tests for the robustness of our results. First, we employ Institutional Investor's country risk scores as alternative dependent variable. ${ }^{21}$ The ratings are based on a survey of leading international banks who are asked to rate each country on a scale from zero to 100 (with higher values representing more creditworthiness). Institutional Investor averages these ratings, providing greater weights to respondents with higher worldwide exposure and more sophisticated country analysis systems. ${ }^{22}$

Second, OECD countries are arguably less likely to rely on international organizations to provide credibility. In order to make sure that the results are not driven by the wealthy states who enjoy high credibility and are members in many IOs, we rerun the regressions excluding OECD member states.

Third, some of the components included in Euromoney's risk ratings seem to determine country risk rather than being part of it. Good economic performance should, e.g., lead to an improvement in the risk rating whereas large outstanding debt should lead to its deterioration. We pursue two strategies to deal with this. We use a modified version of the indicator using three components that are clearly parts rather than determinants of risk: (i) Political risk, which comprises the risk of non-payment or non-servicing of payment for goods or services, loans, trade-related finance and dividends, and the nonrepatriation of capital that is evaluated by the risk analysts. It thus reflects the perceived probability of governments breaking some of their promises; (ii) the credit ratings assigned to sovereign ratings from Moody's, S\&P and Fitch IBCA, and (iii) the discount on forfaiting reflecting the average maximum tenor for forfaiting and the average spread over riskless countries such as the US. Unfortunately, the detailed categories are available since 1992 only, so we lose almost ten years of observations.

As our alternative strategy to control for the influence of potential determinants of country risk, we include variables to control for these determinants among our set of explanatory variables. Specifically, we employ (i) the ratio of debt service to exports, (ii) state consumption to GNP, and (iii) GDP per capita growth, all taken from the World Bank's World Development Indicators (2007). Arguably, higher values of debt

21 We thank Carmen Reinhart for providing these data (as used in Reinhart et al., 2003).

22 Country risk ratings typically reflect the views of outsiders to a country. Yet, if membership in IOs increases the commitment capacity of governments, this should also be reflected in the domestic perception of the security of property rights. We therefore chose the indicator "property rights" as provided in the Index of Economic Freedom (Kane et al. 2007) as an alternative dependent variable. The indicator can take on values between 1 (best) and 5 (worst) and is available for more than 150 countries. However, none of the membership indicators are significant at conventional levels. 
service and state consumption and lower growth rates should reduce the creditworthiness of a country, ceteris paribus.

Additionally, we control for potential political determinants of country risk likely to be correlated with membership in international organizations. We employ the following variables: (i) the number of veto players within the country. We are interested in the additional commitment capacity that a country can gain from becoming member in a number of international organizations beyond the commitment capacity that is founded on the separation of powers domestically. The variable is included based on the assumption that a higher number of domestic veto players could confer higher levels of credibility onto the respective governments. The variable is the CHECKS-variable from the Database of Political Institutions (Beck et al. 2000). (ii) indicators for external and, respectively, internal conflict provided by the International Country Risk Guide (ICRG). Conflict is measured on a scale of $1-12$, where higher values imply less risk of conflict. The indicators measure the perceptions of the likelihood that the government in power will be destabilized or overthrown by possibly unconstitutional and/or violent means. High degrees of (perceived) political instability could lead to low risk ratings which is why we control for them. (iii) We use the democracy/autocracy variable as published in Polity IV (taken from Marshall and Jaggers 2004) to control for the possibility that the degree of realized democracy has an impact on the credibility of a regime, while at the same time being correlated with membership in international organizations..$^{23}$

As our final test for robustness we employ two alternative indicators of institutional quality. First, we use the political rights index provided by Freedom House (2007). The index ranges from 1 to 7 , where higher values reflect less liberty. Our second alternative is the overall ICRG institutional quality index. ICRG employs a blend of quantitative and qualitative measures to calculate their composite index, using five financial, thirteen political and six economic factors. Each factor is assigned a numerical rating within a specified range, where higher scores represent lower risk. Arguably, while the overall ICRG index is frequently used as a measure of institutional quality (e.g., Chong and Calderón 2000), it to some extent also reflects country risk as measured by our dependent variable. While thus not being the perfect measure of institutional quality for our purposes, we still use it to test for robustness.

23 According to Aidt and Gassebner (2007), e.g., the political system has long lasting effects on trade relations. 
Table 4: Membership in IOs and Country Risk, test for robustness I

\begin{tabular}{|c|c|c|c|c|c|c|c|c|c|}
\hline & (1) & $(2)$ & (3) & (4) & $(5)$ & $(6)$ & (7) & $(8)$ & $(9)$ \\
\hline & \multicolumn{3}{|c|}{ Institutional Investor } & \multicolumn{3}{|c|}{ Euromoney, without OECD } & \multicolumn{3}{|c|}{ Euromoney, modified index } \\
\hline Membership in IOs (t-1) & $\begin{array}{l}0.008 \\
(0.85)\end{array}$ & & & $\begin{array}{l}0.031 \\
(0.72)\end{array}$ & & & $\begin{array}{l}0.002 \\
(0.18)\end{array}$ & & \\
\hline $\begin{array}{l}\text { Membership in selected IOs, } \\
\text { unweighted (t-1) }\end{array}$ & & $\begin{array}{c}0.905 \\
(1.84)^{*}\end{array}$ & & & $\begin{array}{c}3.582 \\
(2.27)^{* *}\end{array}$ & & & $\begin{array}{l}0.588 \\
(0.70)\end{array}$ & \\
\hline $\begin{array}{l}\text { Membership in selected IOs, } \\
\text { weighted (t-1) }\end{array}$ & & & $\begin{array}{c}4.906 \\
(3.02)^{* * *}\end{array}$ & & & $\begin{array}{c}15.178 \\
(2.76)^{* * *}\end{array}$ & & & $\begin{array}{l}4.975 \\
(1.46)\end{array}$ \\
\hline Law and order & $\begin{array}{c}0.186 \\
(3.43)^{* * *}\end{array}$ & $\begin{array}{c}0.141 \\
(3.20)^{* * *}\end{array}$ & $\begin{array}{c}0.154 \\
(3.48)^{* * *}\end{array}$ & $\begin{array}{c}0.422 \\
(3.04)^{* * *}\end{array}$ & $\begin{array}{c}0.455 \\
(4.11)^{* * *}\end{array}$ & $\begin{array}{c}0.453 \\
(4.09)^{* * *}\end{array}$ & $\begin{array}{c}8.036 \\
(6.29)^{* * *}\end{array}$ & $\begin{array}{c}7.464 \\
(6.90)^{* * *}\end{array}$ & $\begin{array}{c}7.438 \\
(6.87)^{* * *}\end{array}$ \\
\hline (log) GDP per capita & $\begin{array}{c}2.623 \\
(3.00)^{* * *}\end{array}$ & $\begin{array}{c}2.316 \\
(3.61)^{* * *}\end{array}$ & $\begin{array}{c}2.415 \\
(3.82)^{* * *}\end{array}$ & $\begin{array}{r}1.676 \\
(0.90)\end{array}$ & $\begin{array}{c}2.858 \\
(2.03)^{* *}\end{array}$ & $\begin{array}{c}3.158 \\
(2.22)^{* *}\end{array}$ & $\begin{array}{c}0.267 \\
(3.89)^{* * *}\end{array}$ & $\begin{array}{c}0.240 \\
(3.80)^{* * *}\end{array}$ & $\begin{array}{c}0.247 \\
(3.85)^{* * *}\end{array}$ \\
\hline Trade ( $\%$ of GDP) & $\begin{array}{l}-0.004 \\
(0.55)\end{array}$ & $\begin{array}{r}-0.005 \\
(0.83)\end{array}$ & $\begin{array}{l}-0.004 \\
(0.65)\end{array}$ & $\begin{array}{l}-0.029 \\
(1.90)^{*}\end{array}$ & $\begin{array}{l}-0.024 \\
(2.12)^{* *}\end{array}$ & $\begin{array}{l}-0.020 \\
(1.74)^{*}\end{array}$ & $\begin{array}{l}-0.018 \\
(2.37)^{* *}\end{array}$ & $\begin{array}{l}-0.016 \\
(2.46)^{* *}\end{array}$ & $\begin{array}{l}-0.017 \\
(2.50)^{* *}\end{array}$ \\
\hline Dependent variable (t-1) & $\begin{array}{c}1.370 \\
(27.80)^{* * *}\end{array}$ & $\begin{array}{c}1.373 \\
(30.52)^{* * *}\end{array}$ & $\begin{array}{c}1.365 \\
(30.37)^{* * *}\end{array}$ & $\begin{array}{c}0.599 \\
(14.39)^{* * *}\end{array}$ & $\begin{array}{c}0.550 \\
(15.99)^{* * *}\end{array}$ & $\begin{array}{c}0.544 \\
(15.84)^{* * *}\end{array}$ & $\begin{array}{c}0.522 \\
(11.69)^{* * *}\end{array}$ & $\begin{array}{c}0.502 \\
(12.18)^{* * *}\end{array}$ & $\begin{array}{c}0.500 \\
(12.18)^{* * *}\end{array}$ \\
\hline Dependent variable (t-2) & $\begin{array}{c}-0.522 \\
(10.50)^{* * *}\end{array}$ & $\begin{array}{c}-0.512 \\
(11.12)^{* * *}\end{array}$ & $\begin{array}{c}-0.508 \\
(11.01)^{* * *}\end{array}$ & $\begin{array}{l}0.063 \\
(1.61)\end{array}$ & $\begin{array}{c}0.090 \\
(2.82)^{* * *}\end{array}$ & $\begin{array}{c}0.089 \\
(2.81)^{* * *}\end{array}$ & $\begin{array}{c}0.008 \\
(0.22)\end{array}$ & $\begin{array}{l}0.023 \\
(0.66)\end{array}$ & $\begin{array}{l}0.019 \\
(0.53)\end{array}$ \\
\hline Constant & $\begin{array}{l}-17.088 \\
(2.56)^{* *}\end{array}$ & $\begin{array}{c}-15.059 \\
(3.00)^{* * *}\end{array}$ & $\begin{array}{c}-17.737 \\
(3.56)^{* * *}\end{array}$ & $\begin{array}{l}-1.659 \\
(0.13)\end{array}$ & $\begin{array}{c}-10.952 \\
(1.14)\end{array}$ & $\begin{array}{c}-15.831 \\
(1.58)\end{array}$ & $\begin{array}{c}-55.233 \\
(5.99)^{* * *}\end{array}$ & $\begin{array}{c}-49.290 \\
(6.32)^{* * *}\end{array}$ & $\begin{array}{c}-51.138 \\
(6.52)^{* * *}\end{array}$ \\
\hline Observations & 1270 & 1520 & 1520 & 1139 & 1467 & 1467 & 1093 & 1232 & 1232 \\
\hline Number of countries & 81 & 83 & 83 & 74 & 88 & 88 & 104 & 118 & 118 \\
\hline R-squared (within) & 0.92 & 0.93 & 0.93 & 0.64 & 0.64 & 0.64 & 0.53 & 0.51 & 0.51 \\
\hline
\end{tabular}

Notes: All regressions include fixed country and year dummies.

(robust, absolute) t-statistics in parentheses: * significant at $10 \%$ level; ** significant at $5 \%$ level; *** significant at $1 \%$ level. 
Columns $1-3$ of Table 4 report the results with the alternative dependent variable - the credit rating provided by Institutional Investor - while columns $4-6$ show the results when OECD countries are excluded (again using the original dependent variable). The results show that the simple membership indicator is not significant at conventional levels, while membership in selected organizations reduces risk at the ten percent level at least. Comparing the coefficients of columns 5 and 6 with those reported in columns 2 and 3 of Table 1 shows, interestingly, a substantial increase when excluding OECD countries. Specifically, an increase in the membership index by 0.1 reduces country risk by 0.36 according to the unweighted indicator and, respectively, 1.5 according to the weighted one. This suggests that membership in international organizations is more important for non-OECD countries.

Columns $7-8$ report the results with the modified Euromoney ratings as dependent variable. According to the results, none of our proxies for delegation affects risk at conventional levels of significance. In order to test whether this result is due to the change in the dependent variable or, alternatively, the substantially reduced period under observation, we replicated the analysis employing the original index for the same reduced period of time. The results employing the original index are almost identical, suggesting that the shorter period of time is responsible for the insignificant coefficients. In fact, correlation between the original and the modified index is very high (0.97), suggesting that the previous results are not affected by the inclusion of components likely to determine rather than measure risk.

What happens if the additional variables are taken into account? This is done in Table 5. While columns $1-3$ only include the economic variables included to control for economic determinants of risk covered by the dependant variable, columns $4-6$ also include the additional political variables. As expected, higher debt service increases country risk whereas higher growth improves it according to all specifications, at least at the ten percent level of significance. To the contrary, and unexpectedly, country risk decreases significantly with higher government consumption. The degree of checks and balances is also significant at the ten percent level at least, showing that checks and balances increase country risk, surprisingly. Throughout, the absence of internal conflict significantly decreases risk, while external conflict and democracy are never significant at conventional levels. Note that openness to trade is now significant at the five percent level at least, with a negative coefficient. It thus seems that openness increases risk rather then decreasing it. ${ }^{24}$ Most importantly, however, membership in selected international organizations is again significant at the ten percent level at least

24 This result is in line with Rodrik (1998), arguing globalization to increase individuals' risk of being unemployed. 
for the unweighted version and, respectively, the one percent level for the weighted indicator, showing that the previous results are not affected by the omission of potentially relevant variables.

Table 5: Membership in IOs and Country Risk, test for robustness II

\begin{tabular}{|c|c|c|c|c|c|c|}
\hline & $(1)$ & $(2)$ & (3) & $(4)$ & $(5)$ & (6) \\
\hline Membership in IOs (t-1) & $\begin{array}{l}0.027 \\
(0.72)\end{array}$ & & & $\begin{array}{l}0.045 \\
(1.13)\end{array}$ & & \\
\hline $\begin{array}{l}\text { Membership in selected IOs, } \\
\text { unweighted (t-1) }\end{array}$ & & $\begin{array}{c}4.001 \\
(2.30)^{* *}\end{array}$ & & & $\begin{array}{c}3.595 \\
(1.95)^{*}\end{array}$ & \\
\hline $\begin{array}{l}\text { Membership in selected IOs, } \\
\text { weighted (t-1) }\end{array}$ & & & $\begin{array}{c}18.149 \\
(3.14)^{* * *}\end{array}$ & & & $\begin{array}{c}20.734 \\
(3.50)^{* * *}\end{array}$ \\
\hline Law and order & $\begin{array}{c}0.310 \\
(2.26)^{* *}\end{array}$ & $\begin{array}{c}0.292 \\
(2.66)^{* * *}\end{array}$ & $\begin{array}{c}0.311 \\
(2.84)^{* * *}\end{array}$ & $\begin{array}{l}0.087 \\
(0.59)\end{array}$ & $\begin{array}{l}0.122 \\
(0.99)\end{array}$ & $\begin{array}{l}0.107 \\
(0.87)\end{array}$ \\
\hline (log) GDP per capita & $\begin{array}{r}1.809 \\
(0.90)\end{array}$ & $\begin{array}{l}2.393 \\
(1.53)\end{array}$ & $\begin{array}{l}2.803 \\
(1.78)^{*}\end{array}$ & $\begin{array}{l}2.215 \\
(1.07)\end{array}$ & $\begin{array}{c}2.808 \\
(1.69)^{*}\end{array}$ & $\begin{array}{c}3.437 \\
(2.05)^{* *}\end{array}$ \\
\hline GDP growth & $\begin{array}{c}0.305 \\
(5.66)^{* * *}\end{array}$ & $\begin{array}{c}0.309 \\
(6.88)^{* * *}\end{array}$ & $\begin{array}{c}0.297 \\
(6.69)^{* * *}\end{array}$ & $\begin{array}{c}0.295 \\
(5.27)^{* * *}\end{array}$ & $\begin{array}{c}0.307 \\
(6.60)^{* * *}\end{array}$ & $\begin{array}{c}0.291 \\
(6.37)^{* * *}\end{array}$ \\
\hline Trade ( $\%$ of GDP) & $\begin{array}{c}-0.047 \\
(3.13)^{* * *}\end{array}$ & $\begin{array}{c}-0.032 \\
(2.59)^{* * *}\end{array}$ & $\begin{array}{c}-0.028 \\
(2.32)^{* *}\end{array}$ & $\begin{array}{c}-0.052 \\
(3.45)^{* * *}\end{array}$ & $\begin{array}{c}-0.035 \\
(2.79)^{* * *}\end{array}$ & $\begin{array}{c}-0.032 \\
(2.56)^{* *}\end{array}$ \\
\hline Debt service ( $\%$ of exports) & $\begin{array}{c}-0.059 \\
(2.70)^{* * *}\end{array}$ & $\begin{array}{l}-0.043 \\
(2.24)^{* *}\end{array}$ & $\begin{array}{l}-0.049 \\
(2.58)^{* *}\end{array}$ & $\begin{array}{l}-0.056 \\
(2.35)^{* *}\end{array}$ & $\begin{array}{l}-0.043 \\
(1.96)^{* *}\end{array}$ & $\begin{array}{l}-0.049 \\
(2.27)^{* *}\end{array}$ \\
\hline Gov. consump. (\% of GDP) & $\begin{array}{c}0.129 \\
(1.77)^{*}\end{array}$ & $\begin{array}{c}0.125 \\
(2.05)^{* *}\end{array}$ & $\begin{array}{c}0.130 \\
(2.12)^{* *}\end{array}$ & $\begin{array}{c}0.152 \\
(2.03)^{* *}\end{array}$ & $\begin{array}{c}0.153 \\
(2.36)^{* *}\end{array}$ & $\begin{array}{c}0.161 \\
(2.49)^{* *}\end{array}$ \\
\hline Checks and balances & & & & $\begin{array}{l}-0.263 \\
(1.93)^{*}\end{array}$ & $\begin{array}{l}-0.306 \\
(2.35)^{* *}\end{array}$ & $\begin{array}{c}-0.292 \\
(2.29)^{* *}\end{array}$ \\
\hline External conflict, index & & & & $\begin{array}{l}0.019 \\
(0.11)\end{array}$ & $\begin{array}{r}-0.020 \\
(0.15)\end{array}$ & $\begin{array}{l}0.064 \\
(0.49)\end{array}$ \\
\hline Internal conflict, index & & & & $\begin{array}{c}0.525 \\
(3.48)^{* * *}\end{array}$ & $\begin{array}{c}0.384 \\
(2.91)^{* * *}\end{array}$ & $\begin{array}{c}0.412 \\
(3.15)^{* * *}\end{array}$ \\
\hline Democracy, index & & & & $\begin{array}{l}0.049 \\
(0.62)\end{array}$ & $\begin{array}{c}0.013 \\
(0.19)\end{array}$ & $\begin{array}{l}0.010 \\
(0.15)\end{array}$ \\
\hline Dependent variable (t-1) & $\begin{array}{c}0.586 \\
(14.02)^{* * *}\end{array}$ & $\begin{array}{c}0.545 \\
(15.79)^{* * *}\end{array}$ & $\begin{array}{c}0.536 \\
(15.51)^{* * *}\end{array}$ & $\begin{array}{c}0.579 \\
(13.62)^{* * *}\end{array}$ & $\begin{array}{c}0.543 \\
(15.25)^{* * *}\end{array}$ & $\begin{array}{c}0.530 \\
(14.93)^{* * *}\end{array}$ \\
\hline Dependent variable (t-2) & $\begin{array}{c}0.111 \\
(2.95)^{* * *}\end{array}$ & $\begin{array}{c}0.120 \\
(3.84)^{* * *}\end{array}$ & $\begin{array}{c}0.118 \\
(3.83)^{* * *}\end{array}$ & $\begin{array}{c}0.110 \\
(2.93)^{* * *}\end{array}$ & $\begin{array}{c}0.114 \\
(3.60)^{* * *}\end{array}$ & $\begin{array}{c}0.111 \\
(3.57)^{* * *}\end{array}$ \\
\hline Constant & $\begin{array}{c}-3.599 \\
(0.26)\end{array}$ & $\begin{array}{r}-8.949 \\
(0.83)\end{array}$ & $\begin{array}{c}-15.082 \\
(1.37)\end{array}$ & $\begin{array}{r}-9.162 \\
(0.63)\end{array}$ & $\begin{array}{c}-12.409 \\
(1.09)\end{array}$ & $\begin{array}{l}-21.534 \\
(1.83)^{*}\end{array}$ \\
\hline Observations & 1078 & 1357 & 1357 & 1030 & 1292 & 1292 \\
\hline Number of countries & 73 & 87 & 87 & 72 & 86 & 86 \\
\hline R-squared (within) & 0.69 & 0.67 & 0.68 & 0.69 & 0.67 & 0.67 \\
\hline
\end{tabular}

Notes: The dependent variable is Euromoney's risk rating. All regressions include fixed country and year dummies.

(robust, absolute) t-statistics in parentheses: * significant at $10 \%$ level; $* *$ significant at $5 \%$ level; *** significant at $1 \%$ level. 
Table 6: IOs - Substitutes or Complements, test for robustness

\begin{tabular}{|c|c|c|c|c|c|c|}
\hline & (1) & (2) & (3) & (4) & (5) & (6) \\
\hline Membership in IOs (t-1) & $\begin{array}{c}0.051 \\
(1.74)^{*}\end{array}$ & & & $\begin{array}{c}0.091 \\
(2.61)^{* * *}\end{array}$ & & \\
\hline $\begin{array}{l}\text { Membership in selected IOs, } \\
\text { unweighted (t-1) }\end{array}$ & & $\begin{array}{c}4.124 \\
(2.85)^{* * *}\end{array}$ & & & $\begin{array}{l}-0.363 \\
(0.20)\end{array}$ & \\
\hline $\begin{array}{l}\text { Membership in selected IOs, } \\
\text { weighted (t-1) }\end{array}$ & & & $\begin{array}{c}10.902 \\
(2.65)^{* * *}\end{array}$ & & & $\begin{array}{l}10.641 \\
(1.79)^{*}\end{array}$ \\
\hline Political rights, index & $\begin{array}{l}0.275 \\
(1.03)\end{array}$ & $\begin{array}{l}0.153 \\
(0.75)\end{array}$ & $\begin{array}{r}0.258 \\
(1.21)\end{array}$ & & & \\
\hline Political risk, index & & & & $\begin{array}{c}0.337 \\
(9.68)^{* * *}\end{array}$ & $\begin{array}{c}0.222 \\
(8.51)^{* * *}\end{array}$ & $\begin{array}{c}0.244 \\
(8.29)^{* * *}\end{array}$ \\
\hline IOs * Political rights & $\begin{array}{l}0.007 \\
(1.40)\end{array}$ & & & & & \\
\hline $\begin{array}{l}\text { Selected IOs * Political rights } \\
\text { (weighted) }\end{array}$ & & $\begin{array}{l}0.181 \\
(0.77)\end{array}$ & & & & \\
\hline $\begin{array}{l}\text { Selected IOs * Political rights } \\
\text { (unweighted) }\end{array}$ & & & $\begin{array}{l}0.135 \\
(0.27)\end{array}$ & & & \\
\hline IOs * Political risk & & & & $\begin{array}{l}-0.001 \\
(1.97)^{* *}\end{array}$ & & \\
\hline $\begin{array}{l}\text { Selected IOs * Political risk } \\
\text { (weighted) }\end{array}$ & & & & & $\begin{array}{c}0.048 \\
(2.06)^{* *}\end{array}$ & \\
\hline $\begin{array}{l}\text { Selected IOs * Political risk } \\
\quad \text { (unweighted) }\end{array}$ & & & & & & $\begin{array}{l}0.018 \\
(0.30)\end{array}$ \\
\hline (log) GDP per capita & $\begin{array}{c}3.786 \\
(1.99)^{* *}\end{array}$ & $\begin{array}{c}3.888 \\
(3.31)^{* * *}\end{array}$ & $\begin{array}{c}3.871 \\
(3.33)^{* * *}\end{array}$ & $\begin{array}{l}1.390 \\
(0.71)\end{array}$ & $\begin{array}{l}0.995 \\
(0.81)\end{array}$ & $\begin{array}{l}1.142 \\
(0.92)\end{array}$ \\
\hline Trade (\% of GDP) & $\begin{array}{l}-0.026 \\
(1.89)^{*}\end{array}$ & $\begin{array}{l}-0.011 \\
(1.23)\end{array}$ & $\begin{array}{r}-0.010 \\
(1.11)\end{array}$ & $\begin{array}{c}-0.031 \\
(2.40)^{* *}\end{array}$ & $\begin{array}{c}-0.022 \\
(2.18)^{* *}\end{array}$ & $\begin{array}{l}-0.021 \\
(2.11)^{* *}\end{array}$ \\
\hline Dependent variable $(\mathrm{t}-1)$ & $\begin{array}{c}0.550 \\
(15.83)^{* * *}\end{array}$ & $\begin{array}{c}0.540 \\
(20.71)^{* * *}\end{array}$ & $\begin{array}{c}0.539 \\
(20.73)^{* * *}\end{array}$ & $\begin{array}{c}0.472 \\
(14.98)^{* * *}\end{array}$ & $\begin{array}{c}0.487 \\
(18.62)^{* * *}\end{array}$ & $\begin{array}{c}0.486 \\
(18.63)^{* * *}\end{array}$ \\
\hline Dependent variable (t-2) & $\begin{array}{r}0.054 \\
(1.60)\end{array}$ & $\begin{array}{c}0.061 \\
(2.52)^{* *}\end{array}$ & $\begin{array}{c}0.060 \\
(2.46)^{* * *}\end{array}$ & $\begin{array}{c}0.055 \\
(1.71)^{*}\end{array}$ & $\begin{array}{c}0.048 \\
(1.93)^{*}\end{array}$ & $\begin{array}{c}0.046 \\
(1.87)^{*}\end{array}$ \\
\hline Constant & $\begin{array}{l}-9.862 \\
(0.71)\end{array}$ & $\begin{array}{c}-13.684 \\
(1.60)\end{array}$ & $\begin{array}{l}-14.611 \\
(1.72)^{*}\end{array}$ & $\begin{array}{l}-6.270 \\
(0.43) \\
\end{array}$ & $\begin{array}{l}-0.077 \\
(0.01)\end{array}$ & $\begin{array}{l}-6.630 \\
(0.70)\end{array}$ \\
\hline Observations & 1599 & 2336 & 2336 & 1426 & 2000 & 2000 \\
\hline Number of countries & 113 & 136 & 136 & 104 & 118 & 118 \\
\hline R-squared (within) & 0.54 & 0.54 & 0.54 & 0.59 & 0.59 & 0.59 \\
\hline
\end{tabular}

Notes: The dependent variable is Euromoney's risk rating. All regressions include fixed country and year dummies.

(robust, absolute) t-statistics in parentheses: * significant at $10 \%$ level; $* *$ significant at $5 \%$ level; significant at $1 \%$ level. 
Table 6 turns to describing the results using political rights and, respectively, political risk as alternative indicators of institutional quality. As it turns out, the political rights index and its interaction with the respective membership indicator are completely insignificant according to all regressions (column $1-3$ ), while membership in international organizations is significantly positive independent of the indicator used, at least at the ten percent level. Using the ICRG index of institutional quality instead shows a different picture. According to the three specifications reported in columns $4-$ 6 , better institutional quality reduces country risk, at the one percent level of significance. However, in only one specification, the membership indicator and its interaction with institutional quality are also significant at conventional levels. This is true for membership in all international organizations, where membership itself again reduces risk, and the interaction increases risk. According to column 4, membership in an additional organization reduces risk by 0.1 points (at the one percent level of significance) at the minimum level of political risk among our sample (22) and is not significant at conventional levels at the maximum.

To summarize, there is strong evidence that membership in international organizations reduces country risk. There is also evidence that credibility provided by international organizations substitutes for domestic credibility. However, while the first result is quite robust, the latter depends on how institutional quality is measured.

\section{Conclusion and Outlook}

We have constructed three variables indicating the degree to which countries are members in IOs. Membership is interpreted as a partial delegation of decision-making competence to the international level and an attempt to make policy announcements more credible. Using panel data for up to 136 countries and the period from 1984 to 2004, our results show that higher degrees of membership in international organizations are robustly correlated with lower country risk ratings. Two additional results stand out: (1) length of membership matters; the longer a country has been a member of an IO, the better its risk rating, ceteris paribus. (2) Membership in IOs is particularly important for a country's credibility when domestic institutions are weak. This is shown by two different approaches: (i) the coefficients for the membership variables are particularly high when OECD member countries have been excluded from the panel and (ii) the interaction of proxies for domestic institutional quality with domestic institutional quality increases risk. Up to a degree, credibility can, hence, not only be "made" but also be "bought."

Nevertheless, this paper can only be the first step in estimating the credibilityenhancing effects of IO membership. It would, e.g., be interesting to estimate the costs 
of exiting IOs explicitly. On a more fundamental level, the sanctioning machinery of IOs deserves more explicit analysis: how does it work, how has the right to use it been applied, who has incentives to do so etc.

The main goal of this paper has been to lay the foundations for estimating the effects of an international delegation of power for the credibility of national governments. It is important to keep in mind that this is by no means the only function of IOs. If one is interested in their effects on internalizing border-crossing externalities, in encouraging cooperation and the like, other approaches are thus needed.

Other aspects that need to be dealt with in future work include the endogenization of the delegation decisions. Under what circumstances - one would ask - are politicians particularly prone to delegate powers internationally? How can we explain that competences in some areas (like monetary policy) are more likely to be delegated than policy competences in other areas?

This leads directly to the next question, namely the normative issue: how much competence should be delegated? Will too much delegation lead to a hollowing out of democracy, ${ }^{25}$ will it lead to lower degrees of legitimacy etc. What policy-areas should optimally be delegated to domestic agencies and what areas to international agencies?

${ }^{25}$ See Frey and Stutzer (2006) for an interesting approach to address the democratic deficit of international organizations. 


\section{References}

Aidt, T. and M. Gassebner (2007); Do autocracies trade less? Cambridge Working Papers in Economics 0742, University of Cambridge.

Arellano, M. and S. Bond (1991); Some Tests for Specification for Panel Data: Monte Carlo Evidence and an Application to Employment Equations, Review of Economic Studies 58(2): 277-297.

Arellano, M. and O. Bover (1995); Another Look at the Instrumental Variable Estimation of Error-components Models, Journal of Econometrics 68(1): 29-51.

Barzel, Y. (1997); Parliament as a Wealth-Maximizing Institution: The Right to the Residual and the Right to Vote, International Review of Law and Economics 17: 45574.

Beck, Th., G. Clarke, A. Groff, Ph. Keefer, P. Walsh (2000); New tools and new tests in comparative political economy: The Database of Political Institutions, Washington: The World Bank.

Blume, L. and S. Voigt (2007); The Economic Effects of Human Rights, Kyklos 60(4): 509-38.

Blundell, R. and S. Bond (1998); Initial Conditions and Moment Restrictions in Dynamic Panel Data Models, Journal of Econometrics 87(1): 115-143.

Chong, A. and C. Calderón (2000); Institutional quality and poverty measures in a cross-section of countries, Economics of Governance 1(2): 123-135.

Cosset, J.-C. and J. Roy (1991); The Determinants of Country Risk Ratings, Journal of International Business Studies 22(1): 135-142.

Dreher, A., N. Gaston and P. Martens (2008); Measuring Globalization - Gauging its Consequences, New York: Springer (2008).

Dreher, A., J.-E. Sturm and J.R. Vreeland (2006); Does membership on the UN Security Council influence IMF decisions? Evidence from panel data KOF Working Paper 151, ETH Zurich.

Dreher, A., J.-E. Sturm and J.R. Vreeland (2007); Development Aid and International Politics: Does membership on the UN Security Council influence World Bank decisions? Journal of Development Economics, forthcoming.

Euromoney (various years); Country Risk Survey, available at: http://www.euromoney.com.

Feder, G. and K. Ross (1982); Risk Assessment and Risk Premiums in the Eurodollar Market, Journal of Finance 37:679-91.

Feld, L. und S. Voigt (2003); Economic Growth and Judicial Independence: Cross Country Evidence Using a New Set of Indicators, European Journal of Political Economy, 19(3): 497-527.

Freedom House (2007), Freedom in the World Country Ratings.

Frey, B.S. and A. Stutzer (2006); Strengthening the Citizens' Role in International Organizations, Review of International Organizations 1(1): 27-43. 
Henisz, W. (2000); The Institutional Environment for Economic Growth, Economics and Politics 12: 1-31.

International Centre for the Settlement of Investment Disputes (2006); About ICSID, webpage at: http://www.worldbank.org/icsid/

Institutional Investor (various years); Country Credit Ratings, http://www.institutionalinvestor.com/.

International Country Risk Guide (various years), Country Rankings, The PRS Group, http://www.prsgroup.com/.

Kaja, A. and E. Werker (2007); Institutionalized Insiders: Board Membership and Loan Commitments at the World Bank, paper presented at the First Conference on the Political Economy of International Organizations.

Kane, T., K. Holmes and M.A. O'Grady (2003); Index of Economic Freedom, The Heritage Foundation, http://www.heritage.org/research/features/index/downloads.cfm.

Keefer, Ph. and S. Knack (2003); Social Polarization, Political Institutions, and Country Creditworthiness, in: J.C. Heckelman and D. Coates (eds.): Collective Choice - Essays in Honor of Mancur Olson, Berlin et al.: Springer, 165-86.

Kuziemko, I. and E. Werker (2006); How Much Is a Seat on the Security Council Worth? Foreign Aid and Bribery at the United Nations, Journal of Political Economy 114(5): 905-930.

Kydland, F. and E. Prescott (1977); Rules Rather than Discretion: The Inconsistency of the Optimal Plans, Journal of Political Economy 85: 473-91.

Landes, W. and R. Posner (1975); The Independent Judiciary in an Interest-Group Perspective, The Journal of Law and Economics 18(3): 875-911.

Levy, B. and P. Spiller (1994); The Institutional Foundations of Regulatory Commitment: A Comparative Analysis of Telecommunications Regulation, Journal of Law, Economics \& Organization 10/2: 201-46.

Majone, G. (1996); Temporal Consistency and Policy Credibility: Why Democracies Need Non-Majoritarian Institutions, European University Institute, Working Paper RSC No. 96/57.

Majone, G. (2001); Nonmajoritarian Institutions and the Limits of Democratic Governance: A Political Transaction-Cost Approach, Journal of Institutional and Theoretical Economics 157: 57-78.

Marchesi, S. and J.P. Thomas (1999); IMF conditionality as a screening device, Economic Journal 109: 111-125.

Marchesi, S. and L. Sabani (2007); IMF concern for reputation and conditional lending failure: theory and empirics, Journal of Development Economics: 640-666.

Marshall, K. and M.G. Jaggers (2004); Polity IV Data Set, http://www.cidem.umd.edu/.

Moser, P. (1999); Checks and Balances and the supply of central bank independence, European Economic Review 43: 1569-93.

Nickell, S. J. (1981); Biases in Dynamic Models with Fixed Effects, Econometrica 49: 1417-1426. 
Reinhart, C.M., K.S. Rogoff and M.A. Savastano (2003); Debt Intolerance, Brookings Papers on Economic Activity 2003(1): 1-74.

Reynaud, J. and J. Vauday (2007); Geopolitics and International Organizations - An Empirical Study on IMF Facilities, CILAE Working Paper DT/03/07.

Rodrik, D. (1998); Why Do More Open Economies Have Bigger Governments? Journal of Political Economy 106: 997-1032.

Roodman, D. (2005); xtabond2: Stata Module to Extend xtabond Dynamic Panel Data Estimator. Center for Global Development, Washington, D.C. http://econpapers.repec.org/software/ bocbocode/s435901.htm.

Roodman, D. (2006); How to Do xtabond2: An Introduction to "Difference" and "System" GMM in Stata, Center for Global Development Working Paper 103.

Rose, A. (2004); Do We Really Know that the WTO increases Trade? American Economic Review 94(1): 98-114.

Tallberg, J. (2002); Delegation to Supranational Institutions: Why, How, and With What Consequences? West European Politics 25(1): 23-46.

Tsebelis, G. (2002); Veto Players - How Political Institutions Work. New York: Russell Sage Foundation.

Union of International Associations (2006); Yearbook of International Organizations, Munich: K G Saur Verlag.

Vaubel, R. (2006); Principal-agent problems in international organizations, Review of International Organizations 1(2): 125-138.

Vaubel, R., A. Dreher and U. Soylu (2007); Staff growth in international organizations: A principal-agent problem? An empirical analysis, Public Choice 133(3-4): 275-295.

Voigt, S. and E. Salzberger (2002); Choosing Not to Choose: When Politicians Choose to Delegate Powers, Kyklos 55(2): 247-68.

Voigt, S. (2006); The Interplay Between National and International Law - Its Economic Effects Drawing on Four New Indicators, http://papers.ssrn.com/sol3/papers.cfm?abstract_id=925796.

Vreeland, J.R. (2006); IMF program compliance: Aggregate index versus policy specific research strategies, Review of International Organizations 1(4): 359-378.

Vreeland, J.R. (2007); The International Monetary Fund: Politics of Conditional Lending. New York: Routledge.

Weingast, B. (1993); Constitutions as Governance Structures: The Political Foundations of Secure Markets, Journal of Institutional and Theoretical Economics 149(1): 286-311.

Windmeijer, F. (2005); A Finite Sample Correction for the Variance of Linear Efficient Two-step GMM Estimators, Journal of Econometrics 126(1): 25-51.

World Bank (2007); World Development Indicators, CD-Rom, Washington, DC. 


\section{Appendix A: Sources and Definitions}

Variable
Euromoney, index
Euromoney, modified index
Trade (\% of GDP)
Dobt service (\% of exports)
Political rights
(log) GDP per capita
Molitical risk
Memstitutional Investor, index
Membership in IOs (t-1)

\section{Definition}

Risk ratings based on expert views, heads of syndication and loans, as well as data from the World Bank, forfaiting houses and credit rating agencies. Composite of nine categories: political risk (25\% weighting), economic performance (25\%), debt indicators (10\%), debt in default or rescheduled (10\%), credit ratings (10\%), access to bank finance (5\%), access to short-term finance (5\%), access to capital markets (5\%), and discount on forfaiting $(5 \%)$.

Composite of hree components that are clearly parts rather than determinants of risk: (i) Political risk, which comprises the risk of non-payment or non-servicing of payment for goods or services, loans, trade-related finance and dividends, and the nonrepatriation of capital that is evaluated by the risk analysts. It thus reflects the perceived probability of governments breaking some of their promises; (ii) the credit ratings assigned to sovereign ratings from Moody's, S\&P and Fitch IBCA, and (iii) the discount on forfaiting reflecting the average maximum tenor for forfaiting and the average spread over riskless countries such as the US.

Country risk ratings based on a survey of leading international banks, providing greater weights to respondents with higher worldwide exposure and more sophisticated country analysis systems.

Membership in inter-governmental international organizations.

Unweighted indicator of membership in selected international organizations.

Indicator of membership in selected international organizations weighted by years of membership.

Assesses the strength and impartiality of the legal system as well as the popular observance of the law. It ranges from zero to six, where a higher number indicates a better system of law and order.

Overall ICRG institutional quality index employing five financial, thirteen political and six economic factors, where higher scores represent lower risk.

Index of political rights ranging from 1 to 7 , where higher values reflect less liberty.

In constant 2000 US\$.

Annual percentage growth rate of GDP at market prices based on constant local currency. Aggregates are based on constant 2000 U.S. dollars.

Trade is the sum of exports and imports of goods and services measured as a share of gross domestic product.

Sum of principal repayments and interest actually paid in foreign currency, goods, or services on long-term debt, interest paid on short-term debt, and repayments (repurchases and charges) to the IMF.

General government final consumption expenditure.

\section{Source}

Euromoney (various years)

Euromoney

(various years)

Institutional

Investor (various years)

Dreher (2006), updated in Dreher, Gaston and Martens (2008)

various sources as described in the text various sources as described in the text ICRG (various years)

ICRG (various years)

Freedom House (2007)

World Bank

(2007)

World Bank

(2007)

World Bank

(2007)

World Bank

(2007)

World Bank (2007) 
Appendix A (continued)

Variable

Checks and balances
External conflict, index
Internal conflict, index
Democracy, index

Definition

The number of veto players within the country.

Measures perceptions of both of the risk to the incumbent government from foreign action, ranging from non-violent external pressure (diplomatic pressures, withholding of aid, trade restrictions, territorial disputes, sanctions, etc) to violent external pressure (cross-border conflicts to all-out war), on a scale of $1-12$, where higher values imply less risk.

Measures perceptions of political violence in the country and its actual or potential impact on governance, on a scale of $1-12$, where higher values imply less risk. The highest rating is given to those countries where there is no armed opposition to the government and the government does not indulge in arbitrary violence, direct or indirect, against its own people. The lowest rating is given to a country embroiled in an on-going civil war. POLITY IV index of democracy.
Source

Beck et al

(2000)

ICRG (various

years)

ICRG (various years)

Marshall and Jaggers (2004) 
Appendix B: Descriptive Statistics (estimation sample, Table 1, column 1)

Variable

Euromoney, index

Euromoney, modified index

Institutional Investor, index

Membership in IOs (t-1)

Membership in selected IOs, unweighted (t-1)

Membership in selected IOs, weighted ( $t-1)$

Law and order

Political risk

Political rights

(log) GDP per capita

GDP growth

Trade ( $\%$ of GDP)

Debt service (\% of exports)

Government consumption (\% of GDP)

Checks and balances

External conflict, index

Internal conflict, index

Democracy, index

\begin{tabular}{|c|c|}
\hline Obs & Mean \\
\hline 1647 & 53.96 \\
\hline 1275 & 19.06 \\
\hline 1249 & 46.72 \\
\hline 1647 & 49.90 \\
\hline 1647 & 0.73 \\
\hline 1647 & 0.48 \\
\hline 1647 & 7.66 \\
\hline 1647 & 66.32 \\
\hline 1647 & -2.89 \\
\hline 1647 & 7.85 \\
\hline 1645 & 3.28 \\
\hline 1647 & 72.20 \\
\hline 1087 & 20 \\
\hline 1639 & 15.32 \\
\hline 1585 & 3.34 \\
\hline 1645 & 10.25 \\
\hline 1645 & 9.12 \\
\hline 1592 & 4.91 \\
\hline
\end{tabular}

Std. Dev.

Min

$\operatorname{Max}$

\begin{tabular}{|r|}
\hline 25.19 \\
12.03 \\
25.37 \\
13.40 \\
0.20 \\
0.19 \\
3.07 \\
14.53 \\
1.93 \\
1.56 \\
4.14 \\
42.00 \\
13 \\
5.50 \\
1.76 \\
1.84 \\
2.45 \\
6.05 \\
\hline
\end{tabular}

\begin{tabular}{|r|}
\hline 4.00 \\
0.82 \\
6.40 \\
15.00 \\
0.00 \\
0.00 \\
0.83 \\
23.08 \\
-7.00 \\
4.41 \\
-28.10 \\
12.85 \\
0 \\
2.90 \\
1.00 \\
2.00 \\
0.42 \\
-9.00 \\
\hline
\end{tabular}

100.00

40.00

95.90

101.00

1.00

0.94

12.00

96.08

$-1.00$

10.83

27.40

433.23

118

35.44

18.00

12.00

12.00

10.00 


\section{CESifo Working Paper Series}

for full list see www.cesifo-group.org/wp

(address: Poschingerstr. 5, 81679 Munich, Germany, office@cesifo.de)

2221 Michael Melvin, Lukas Menkhoff and Maik Schmeling, Automating Exchange Rate Target Zones: Intervention via an Electronic Limit Order Book, February 2008

2222 Raymond Riezman and Ping Wang, Preference Bias and Outsourcing to Market: A Steady-State Analysis, February 2008

2223 Lars-Erik Borge and Jørn Rattsø, Young and Old Competing for Public Welfare Services, February 2008

2224 Jose Apesteguia, Steffen Huck, Jörg Oechssler and Simon Weidenholzer, Imitation and the Evolution of Walrasian Behavior: Theoretically Fragile but Behaviorally Robust, February 2008

2225 Walter Krämer, Long Memory with Markov-Switching GARCH, February 2008

2226 António Afonso and Christophe Rault, What do we really Know about Fiscal Sustainability in the EU? A Panel Data Diagnostic, February 2008

2227 Sergey M. Kadochnikov and Igor M. Drapkin, Market Structure, Technological Gap and Vertical Linkage Effects from Foreign Direct Investment, February 2008

2228 Guglielmo Maria Caporale, Davide Ciferri and Alessandro Girardi, Fiscal Shocks and Real Exchange Rate Dynamics: Some Evidence for Latin America, February 2008

2229 Scott Alan Carson, Geography and Insolation in $19^{\text {th }}$ Century US African-American and White Statures, February 2008

2230 Wolfgang Buchholz and Jan Schumacher, Discounting and Welfare Analysis Over Time: Choosing the $\eta$, February 2008

2231 M. Hashem Pesaran, Christoph Schleicher and Paolo Zaffaroni, Model Averaging in Risk Management with an Application to Futures Markets, February 2008

2232 Wilhelm Kohler, Offshoring: Why Do Stories Differ?, February 2008

2233 Stefan Bach, Giacomo Corneo and Viktor Steiner, Effective Taxation of Top Incomes in Germany, 1992-2002, February 2008

2234 Robert S. Chirinko, $\sigma:$ The Long And Short Of It, February 2008

2235 Volker Grossmann and Holger Strulik, Should Continued Family Firms Face Lower Taxes than other Estates?, February 2008

2236 Guido Tabellini, The Scope of Cooperation: Values and Incentives, February 2008 
2237 Heinrich W. Ursprung and Christian Wiermann, Reputation, Price, and Death: An Empirical Analysis of Art Price Formation, March 2008

2238 Hans Fehr and Christian Habermann, Private Retirement Savings in Germany: The Structure of Tax Incentives and Annuitization, March 2008

2239 Joseph Francois and Ian Wooton, Market Structure and Market Access, March 2008

2240 Hiroyuki Kasahara and Beverly Lapham, Productivity and the Decision to Import and Export: Theory and Evidence, March 2008

2241 Gary E. Bolton and Axel Ockenfels, Does Laboratory Trading Mirror Behavior in Real World Markets? Fair Bargaining and Competitive Bidding on EBay, March 2008

2242 Atsushi Oshima, B. Ravikumar and Raymond Riezman, Entrepreneurship, Organization Capital and the Evolution of the Firm, March 2008

2243 Walter Krämer and Sebastian Schich, Large-Scale Disasters and the Insurance Industry, March 2008

2244 Leif Danziger, Adjustment Costs, Inventories and Output, March 2008

2245 Anne van Aaken, Lars P. Feld and Stefan Voigt, Power over Prosecutors Corrupts Politicians: Cross Country Evidence Using a New Indicator, March 2008

2246 Hans-Christian Heinemeyer, Max-Stephan Schulze and Nikolaus Wolf, Endogenous Borders? The Effects of New Borders on Trade in Central Europe 1885-1933, March 2008

2247 Johannes Becker and Clemens Fuest, Tax Competition - Greenfield Investment versus Mergers and Acquisitions, March 2008

2248 Giorgio Bellettini and Hubert Kempf, Why not in your Backyard? On the Location and Size of a Public Facility, March 2008

2249 Jose Luis Evia, Roberto Laserna and Stergios Skaperdas, Socio-Political Conflict and Economic Performance in Bolivia, March 2008

2250 Bas Jacobs and A. Lans Bovenberg, Optimal Taxation of Human Capital and the Earnings Function, March 2008

2251 Jan-Egbert Sturm and Timo Wollmershäuser, The Stress of Having a Single Monetary Policy in Europe, March 2008

2252 Guido Schwerdt, Labor Turnover before Plant Closure: 'Leaving the Sinking Ship' vs. 'Captain Throwing Ballast Overboard', March 2008

2253 Keith E. Maskus and Shuichiro Nishioka, Development-Related Biases in Factor Productivities and the HOV Model of Trade, March 2008 
2254 Jeremy Edwards and Sheilagh Ogilvie, Contract Enforcement, Institutions and Social Capital: the Maghribi Traders Reappraised, March 2008

2255 Imed Drine and Christophe Rault, Purchasing Power Parity for Developing and Developed Countries. What can we Learn from Non-Stationary Panel Data Models?, March 2008

2256 Scott Alan Carson, Health, Wealth and Inequality: a Contribution to the Debate about the Relationship between Inequality and Health, March 2008

2257 C.A.E. Goodhart, The Regulatory Response to the Financial Crisis, March 2008

2258 Stefan Bauernschuster, Oliver Falck and Stephan Heblich, The Impact of Continuous Training on a Firm's Innovations, March 2008

2259 Michael Grimm and Stephan Klasen, Geography vs. Institutions at the Village Level, March 2008

2260 Fwu-Ranq Chang, Property Insurance, Portfolio Selection and their Interdependence, March 2008

2261 J. Atsu Amegashie and Marco Runkel, The Paradoxes of Revenge in Conflicts, March 2008

2262 Hans Jarle Kind, Marko Koethenbuerger and Guttorm Schjelderup, Efficiency Enhancing Taxation in Two-sided Markets, March 2008

2263 M. Hashem Pesaran, Til Schuermann and L. Vanessa Smith, Forecasting Economic and Financial Variables with Global VARs, March 2008

2264 Volker Grossmann, Entrepreneurial Innovation and Sustained Long-run Growth without Weak or Strong Scale Effects, March 2008

2265 Robert S. Chirinko and Huntley Schaller, The Irreversibility Premium, March 2008

2266 Andrea Galeotti and José Luis Moraga-González, Platform Intermediation in a Market for Differentiated Products, April 2008

2267 Torben M. Andersen and Michael Svarer, The Role of Workfare in Striking a Balance between Incentives and Insurance in the Labour Market, April 2008

2268 Harald Badinger, Cyclical Fiscal Policy, Output Volatility, and Economic Growth, April 2008

2269 Thomas Aronsson and Erkki Koskela, Outsourcing and Optimal Nonlinear Taxation: A Note, April 2008

2270 Gary E. Bolton, Claudia Loebbecke and Axel Ockenfels, How Social Reputation Networks Interact with Competition in Anonymous Online Trading: An Experimental Study, April 2008 
2271 Nikolaus Wolf, Scylla and Charybdis. Explaining Europe's Exit from Gold, January 1928 - December 1936, April 2008

2272 Michael Funke and Marc Gronwald, The Undisclosed Renminbi Basket: Are the Markets Telling us something about where the Renminbi - US Dollar Exchange Rate is Going?, April 2008

2273 Thor Olav Thoresen and Annette Alstadsæter, Shifts in Organizational Form under a Dual Income Tax System, April 2008

2274 Helge Berger and Volker Nitsch, Too many Cooks? Committees in Monetary Policy, April 2008

2275 Yin-Wong Cheung and Eiji Fujii, Deviations from the Law of One Price in Japan, April 2008

2276 Michael S. Michael, Sajal Lahiri and Panos Hatzipanayotou, Integrated Reforms of Indirect Taxes in the Presence of Pollution, April 2008

2277 Bas Jacobs, Is Prescott Right? Welfare State Policies and the Incentives to Work, Learn and Retire, April 2008

2278 Burkhard Heer and Alfred Maußner, Value Function Iteration as a Solution Method for the Ramsey Model, April 2008

2279 Jarko Fidrmuc and Christa Hainz, Integrating with their Feet: Cross-Border Lending at the German-Austrian Border, April 2008

2280 Kristof Dascher and Alexander Haupt, The Political Economy of Regional Integration Projects at Borders where Rich and Poor Meet: The Role of Cross-Border Shopping and Community Sorting, April 2008

2281 Katrin Assenmacher-Wesche and M. Hashem Pesaran, A VECX* Model of the Swiss Economy, April 2008

2282 Christophe Rault, Robert Sova and Ana Maria Sova, Modeling International Trade Flows between CEEC and OECD Countries, April 2008

2283 Timo Boppart, Josef Falkinger, Volker Grossmann, Ulrich Woitek and Gabriela Wüthrich, Qualifying Religion: The Role of Plural Identities for Educational Production, April 2008

2284 Armin Falk, David Huffman and W. Bentley MacLeod, Institutions and Contract Enforcement, April 2008

2285 Axel Dreher and Stefan Voigt, Does Membership in International Organizations Increase Governments' Credibility? Testing the Effects of Delegating Powers, April 2008 